Célia Regina dos Santos Lopes, Leonardo Lennertz Marcotulio and Thiago Laurentino de Oliveira

\title{
Forms of address from the Ibero-Romance perspective
}

\section{A brief history of Brazilian voceamento}

\begin{abstract}
The objective of this chapter is to map how the new (sub)systems of second person singular address in Brazilian Portuguese (BP) became organized, examining how address forms in subject position correlate with forms in the other positions (accusative, dative, oblique, genitive). We analyze samples of personal letters written by Brazilians in the 19th and 20th centuries from two regions of the country (Southeast and Northeast). In subject position, the results evidence a gradual loss in use of the pronoun $t u$ 'you' to the benefit of the new form você 'you', starting in the first half of the 20th century. In the other morphosyntactic contexts, we found a very irregular distribution of the innovative form você.
\end{abstract}

Keywords: Brazilian Portuguese, address system, subject position, nominative, accusative, genitive, dative, oblique

\section{Introduction}

Ibero-Romance languages such as Portuguese and Spanish historically share parallel processes of change to their address systems that can be compared and contrasted. Having a known common predecessor, inherited from Vulgar Latin, these languages had, by the end of the Middle Ages, the address triad (Pt./Sp.) tu/tú 'you-SG', vós/vos ('you-PL', used to address a singular interlocutor with deference) and vossa mercê/vuestra merced 'lit. Your Mercy', which was then transferred to America. We discuss the grammatical repercussions resulting from these changes in the pronominal system for the second person singular in Brazilian Portuguese (BP), triggered by the inclusion of the new pronoun você 'you' (voceamento ${ }^{1}$ ), resulting from vossa mercê. While we acknowledge the relatively similar

1 Voceamento refers to the system in Brazilian Portuguese that uses the você pronoun of address as a form of intimacy.

Ә Open Access. (C) 2020 Célia Regina dos Santos Lopes et al., published by De Gruyter. (B) BY This work is licensed under a Creative Commons Attribution 4.0 International License.

https://doi.org/10.1515/9783110701234-004 
origins, we do not intend to focus on a discussion of the pragmatic differences between the forms from Europe and from various areas in America.

Therefore, the purpose of this chapter is to present, in broad terms, the results from diachronic studies carried out thus far by a large team of researchers from the Project for the History of Brazilian Portuguese (PHPB, ${ }^{2}$ acronym in Portuguese). The objective is to present the reorganization in the pronominal system for the second person singular in BP, from a geolinguistic and diachronic perspective, based on an analysis of the forms of address found in personal letters written in different locations in the most populous regions of Brazil during the 19th and 20th centuries: the Southeast and the Northeast.

To that end, this chapter is organized as follows. In Section 2, we provide a simple and broad review of the historical evolution of forms of address in Portuguese, arriving at more recent proposals on the development of the subsystems of address in modern BP. We then compare this development to that of Hispanic American voseo ${ }^{3}$, discussed in Rona (1967), Fontanella de Weinberg (1992), Carricaburo (1997), as well as in Hummel et al. (2010) and Bertolotti (2015). Our purpose is simply to illustrate a certain parallelism in terms of the positions occupied by forms from each paradigm in the new pronominal systems for the second person in BP and in Hispanic American voseo. In Section 3, we present the description of the corpus of letters used in this study and, in Section 4, we discuss the reorganizations that took place in subject position in BP. In Section 5, we describe the other grammatical relations, such as the accusative, dative, oblique and genitive. Finally, we map the results obtained, which will serve as a brief and explanatory foundation for future studies, although this is not the case of the proposal advanced here.

2 UFRJ (Universidade Federal do Rio de Janeiro): Célia Lopes, Leonardo Marcotulio, Thiago Oliveira, Rachel Lucena, Janaina Souza, Camila Souza; UFMG (Universidade Federal de Minas Gerais): Márcia Rumeu; UFRN (Universidade Federal do Rio Grande do Norte): Marco Martins, Kássia Moura; UFRPE (Universidade Federal Rural de Pernambuco): Valéria Gomes; UEFS (Universidade Estadual de Feira de Santana): Zenaide Carneiro; Mariana Oliveira, Aroldo Andrade, among others.

3 Voseo refers to the pronoun vos in Hispanic American Spanish as a form of address in the second person singular used in contexts of intimacy. 


\section{The Ibero-Romance dynamics of Brazilian voceamento and Hispanic voseo: a brief review}

In order to understand the development of the new second person pronominal system in modern Brazilian Portuguese (BP), we provide a summarized review of the successive changes that took place in the formal and informal address systems over the course of the history of Portuguese. As we aim to show, certain pronominal forms fell into disuse while the new nominal forms began to take on roles typical of the class of pronouns - a process which provoked a major reconfiguration on the level of formality as well as informality. Table 1 sets out the four stages in the evolution of formal (V) and informal (T) second person in subject position.

Table 1: System of address for the formal (V) and informal (T) second person in subject position in Portuguese: four evolutionary stages.

\begin{tabular}{|c|c|c|c|c|}
\hline Stages & $\mathbf{I}$ & II & III & IV \\
\hline Centuries & $\begin{array}{l}\text { Up to } \\
14 \text { th/15th }\end{array}$ & $\begin{array}{l}\text { 15th to } \\
18 \text { th/19th }\end{array}$ & $\begin{array}{l}\text { End of } 19 \text { th to } \\
\text { first quarter } \\
\text { of } 20 \text { th }\end{array}$ & $\begin{array}{l}\text { During the } \\
20 \text { th } / 21 \mathrm{st}\end{array}$ \\
\hline $\begin{array}{l}\text { Intimacy } \\
{[- \text { formal] }(\mathrm{T})}\end{array}$ & tu & tu & tu & $\begin{array}{l}\text { tu } \\
\text { você }\end{array}$ \\
\hline $\begin{array}{l}\text { Politeness } \\
\text { [+ formal] (V) }\end{array}$ & vós & $\begin{array}{l}\text { vós } \\
\text { vossa mercê }\end{array}$ & você & o/a senhor(a) \\
\hline
\end{tabular}

Similarly to other Romance languages such as Spanish and French, Portuguese inherited from Vulgar Latin a system with two forms of address for the second person singular: the original pronoun $t u$ for the level of informality/proximity and the (primarily plural) pronoun vós for the level of formality/distance ( $T$ and $V$, respectively, according to Brown \& Gilman 1960), as we see in stage I. These forms are distinguished on pragmatic grounds: while the former (T) was used in more informal contexts between equals and in relations from superior to inferior, the latter (V) was a formal address form.

Due to the spread of the vós form to the less privileged strata of society and its consequent pragmatic bleaching, the address system in Portuguese became more complex by the end of the medieval period, with the introduction of new forms in the realm of formality, as is the case of vossa mercê (Faraco 1996), among other nominal forms not mentioned here due to the objectives of this chapter. This new 
form of address in the second person was originally a noun phrase - therefore, a third person form - which was reanalyzed as a form of address in the second person (Marcotulio 2015). For this reason, due to its nominal origin, the new form of address conforms with the entire verbal and pronominal paradigm of the third person.

It is worth noting that, in stage II in Table 1, the Portuguese system had uniform paradigms for the different syntactic functions: nominative (subject), accusative (direct object), dative (indirect object), oblique (verb and noun complements or adjuncts) and genitive (possessive). In other words, the tu, vós and vossa mercê (after você) paradigms were regular and symmetrical. For the tu paradigm, we have, respectively, te, prep. + ti, contigo, teu(s)/tua(s). For vós, we have vos, "prep. + vós", convosco, vosso; and, finally; for vossa mercê > você we have o/a, lhe, você, "prep. + vossa mercê/você", seu(s)/sua(s).

In a similar way to what happened with the formal address pronoun vós, the new form, vossa mercê, also gradually underwent semantic bleaching in its formality/deference feature. At the end of the 15th century, the use of vossa mercê was not limited only to addressing the Portuguese king, broadening its scope to other social spheres such as dukes and heirs, then, noblemen and, in the 16th century, bourgeois who had been on the rise since the 12th century. As a result of a grammaticalization process, from the 17th century on, there were already occurrences of the você form (Rumeu 2013; Faraco 1996), also evidencing an accelerated phonetic deterioration of the original vossa mercê. However, in pragmatic terms, você behaved like a multifunctional address form, since it still had features of $(\mathrm{V})$ address until the beginning of the 20th century, occupying the realm of formality on its own. This is due to the fact that the old vós was in the process of becoming archaic and was consequently abandoned in the 18th century (Cintra 1972; Faraco 1996), as observed in stage III.

The new grammaticalized pronoun você had kept its use as a formal address pronoun in European Portuguese (EP), though its pragmatic value had shifted after the inclusion of new nominal forms such as o senhor/a senhora ('Sir/ Madam'). However, você in Brazilian Portuguese (BP) has taken a different path. From the first quarter of the 20th century, as a consequence of a faster grammaticalization process (compared to EP), we observe a shift of você to the realm of informality in BP (Rumeu 2013). The loss of the $T / V$ pragmatic opposition starts to become increasingly clear in Brazilian documents in the 20th century, in which the $t u$ and você forms coexist as subjects (Rumeu 2013, Souza 2012) in more intimate contexts (stage IV).

In fact, with this overview, we intend to arrive at a single point: to show that the emergence of você did not lead to the disappearance of the older pronoun $(t u)$, but generated a coexistence of different subsystems of pronominal address 
in Brazil with geographical, sociolinguistic and pragmatic variations. Despite the indication that, in stage IV, tu and você would be variants on the level of intimacy, this situation is not exactly the same all over Brazil. Whether você is more or less intimate really depends on the presence of $t u$, which is not always present across the country.

Some proposals, such as the one provided by Scherre et al. $(2009,2015)$ based on research carried out with oral data, have aimed to describe the distribution of the tu and você forms of address in Brazil. Based on various studies carried out until 2012, the authors propose the existence of six subsystems of address in BP, taking into account the agreement patterns noted between the subject pronoun and the verb. In addition to canonical patterns of agreement (tu cantas, você canta 'you sing'), the absence of verbal marking for the second person singular (morpheme -s in this case) with the tu subject is also possible in Brazil: tu cantaØ. In other words, this is a pattern that points to the absence of markings of canonical agreement or, for some authors, agreement with the verb in the third person. The six subsystems are divided as follows:

1) Você: exclusive use of você with its reduced variants ocê and cê. The você subsystem, with the verb consistently in the third person singular, is predominantly concentrated in the central area of Brazil. In the Midwestern region, with the exception of Brasília, it has been identified in the states of Goiás, Mato Grosso and Mato Grosso do Sul. In the Southeastern region, it has been identified in Minas Gerais (with the exception of São João da Ponte) and São Paulo (with the exception of Santos). In the Northeastern region, it appears mostly in the capital of Bahia (Salvador). In the Northern region, it has been found thus far in Tocantins. In the Southern region, it has been found in Paraná.

2) Tu with low verbal agreement: the prevalence of $t u$ is over $60 \%$, with second person verbal agreement (tu cantas) below 10\%, preferring tu canta. This subsystem appears in two regions: North (Amazonas) and South (Rio Grande do Sul).

3) Tu with high verbal agreement: the prevalence of $t u$ is over $60 \%$, with agreement between $40 \%$ and $60 \%$. It also appears at the geographical extremes: North (Pará) and South (Santa Catarina).

4) Tu/você with low verbal agreement: moderate use of tu below $60 \%$, with agreement below 10\%. Identified in the Northeast (Maranhão) and South (Santa Catarina).

5) Tu/você with average verbal agreement: moderate use of $t u$ below $60 \%$, with agreement between $10 \%$ and 39\%. It occurs in various states of the Northeastern Region (Maranhão, Piauí, Ceará, Paraíba, Pernambuco), in the Northern Region (Amazonas) and in the Southern Region (Santa Catarina). 
6) Você/tu without agreement: the use of $t u$ ranges from $1 \%$ to $90 \%$. Identified in all regions of Brazil, except in the Southern Region: Midwest (Federal District), Southeast (Rio de Janeiro and São Paulo, particularly in Santos), Minas Gerais (in the rural area); Northeast (Maranhão, Tocantins, Bahia outside of the capital); North (Rondônia, Acre, Tocantins).

Map 1 provides a general overview of the subsystems described above.

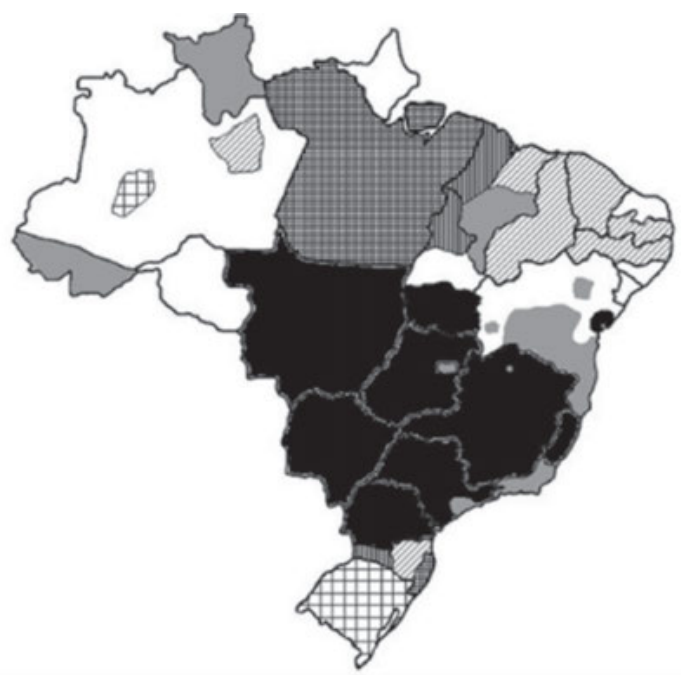

1 - only você, with você/cêlocê variants

2 - more $t u(>60 \%)$ and low agreement with $t u(<10 \%)$

3 - more $t u(>60 \%$ ) and high agreement with $t u$ (from $40 \%$ to $60 \%$ )

$4-t u / v o c \hat{e}(t u<60 \%)$ and low agreement with $t u(<10 \%)$

5 - tu/voce $(t u<60 \%)$ and moderate agreement with $t u$ (from $10 \%$ to $39 \%$ )

6 - você/tu - tu from $1 \%$ to $90 \%$ without agreement

Map 1: Six systems with the second person pronouns você and $t u$ in Brazilian Portuguese (source: Scherre et al. 2015: 142).

For the discussion that we propose in this chapter, we have reduced the six subsystems in Scherre et al. (2015) to only three because, at this point, we do not intend to take into account the issue of verbal agreement. Therefore, we have three subsystems: (i) você, (ii) $t u$ and (iii) você/tu (Lopes \& Cavalcante 2011). This 
amalgam is especially pertinent for historical studies, since they are based on written texts and the inflectional second person markings appear in most cases. In this sense, we have determined that the following pertain to (i) the você subsystem - the individuals/writers who used the você pronoun mostly or exclusively in addressing the interlocutor, as exemplified in example (1); (ii) the tu subsystem the individuals/writers who used the $t u$ form of address with or without agreement markings, as in example (2); and finally (iii) the você/tu subsystem - there is variable use on the part of the individuals/writers, using two forms of address in reference to the interlocutor, as in example (3).

(1) a nave que você pilota há de erguer vôo seguro elevando você às alturas. [first half of the 20th century, MG]

the craft that you pilot has to take flight safe elevating you to the heights.

'the craft that you pilot has to take flight safely lifting you high up'

(2) Eu soube que tu vinhas do dia 4 de Setembro. pediste que tua mãe foste te buscar [first half of the 20th century, RJ]

I heard that you came from the day 4 of September. $\emptyset$ asked that your mother went to you get

'I heard that you were coming on the 4th of September. [You] asked your mother to pick you up'

(3) Você vê minha amizade por meu irmão. Quando visite o tumulo de nossa santa mãe não te $\emptyset$ esqueças de pedir pelas minhas intenções. [1first half of the 20th century, RJ]

You see my friendship for my brother. When visit the tomb of our holy mother not you $\emptyset$ forget to ask for my intentions.

'You see my friendship with my brother. When [you] visit the tomb of our holy mother, do not forget to ask for my intentions'

We must still take into account that the process of change triggered by the inclusion of the grammaticalized pronoun você as a subject together with tu led to important consequences for the rest of the pronominal paradigm. Table 2 sets out the various forms for $t u$ and você as part of a symmetrical and uniform paradigm.

However, we argue that the table presented, along the lines proposed, is restricted to normative descriptions and is not representative of address usage of BP speakers. Though the você form in the role of subject has become, in most of 
Table 2: Symmetrical second person system of address in the various functions.

\begin{tabular}{lllll}
\hline $\begin{array}{l}\text { Nominative } \\
\text { (Subject) }\end{array}$ & $\begin{array}{l}\text { Accusative } \\
\text { (Non-prepositional } \\
\text { complement) }\end{array}$ & $\begin{array}{l}\text { Dative } \\
\text { (Complement } \\
\text { not necessarily } \\
\text { prepositioned) }\end{array}$ & $\begin{array}{l}\text { Oblique } \\
\text { (Prepositional } \\
\text { complement) }\end{array}$ & $\begin{array}{l}\text { Genitive } \\
\text { (Possessive) }\end{array}$ \\
\hline$t u$ & $t e$ & te, a/para ti & prep. + ti, contigo & teu(s)/tua(s) \\
\hline você & $o / a$, você & lhe, a/para você & prep. +você & seu(s)/sua(s) \\
\hline
\end{tabular}

Brazil, a variant of $t u$ on the level of intimacy, in the other grammatical functions, this use has not developed in the same way. This means that forms from the tu paradigm have not completely disappeared, and they are indeed still frequently used in some functions as we intend to show. The new second person paradigm that was established in BP allows, for example, the use of você in the role of subject together with the clitic te (accusative or dative), as in (4a) and (4b), respectively:

(4) a. Você $\hat{e}_{\mathrm{i}}$ sabe que eu $t e_{\mathrm{i}}$ amo.

You know that I you love

'You know that I love you'

b. Voce $\hat{e}_{\mathrm{i}}$ disse que eu $e_{\mathrm{i}}$ dei o livro.

You said that I you gave the book

'You said that I gave you the book'

Table 3 illustrates all the possibilities of the new second person singular (2SG) paradigm in BP. We highlight the most frequent forms from the two paradigms as we will explain below.

Table 3: Development of a new second person paradigm.

\begin{tabular}{lllll}
\hline $\begin{array}{l}\text { Nominative } \\
\text { (Subject) }\end{array}$ & $\begin{array}{l}\text { Accusative } \\
\text { (Non-prepositional } \\
\text { complement) }\end{array}$ & $\begin{array}{l}\text { Dative } \\
\text { (Complement } \\
\text { not necessarily } \\
\text { prepositioned) }\end{array}$ & $\begin{array}{l}\text { Oblique } \\
\text { (Prepositional } \\
\text { complement) }\end{array}$ & $\begin{array}{l}\text { Genitive } \\
\text { (Possessive) }\end{array}$ \\
\hline vocêltu & você, lhe, o/a, te & $\begin{array}{l}\text { lhe, a/para você, } \\
\text { te, alpara ti }\end{array}$ & $\begin{array}{l}\text { prep. + você, } \\
\text { prep. + ti, contigo }\end{array}$ & $\begin{array}{l}\mathrm{seu}(\mathrm{s}) / \mathrm{sua}(\mathrm{s}), \\
\mathrm{teu}(\mathrm{s}) / \mathrm{tua}(\mathrm{s})\end{array}$ \\
\hline
\end{tabular}

Considering the historical background, briefly illustrated in Table 1, the first working hypothesis is that the pronoun você was included more quickly into the pronominal system as a new form of reference to 2SG only in subject role. In the other grammatical relations, this pronoun could be found only in some specific 
positions, such as prepositional complement and genitive (in some contexts and regional areas). Therefore, one of the objectives of this chapter is to diachronically map how the new 2SG (sub)systems of address in BP were established, comparing the subject position with the other positions (accusative, dative, oblique, genitive) (see Section 5). Another hypothesis that will guide this study is based on the similarities of this new paradigm in Brazilian Portuguese with some subsystems of address from Hispanic voseo as we intend to briefly show next. These similarities are not related necessarily to the variant forms themselves, but to the places in the pronominal table in which forms from one or the other paradigm were established.

Within a broader contrastive perspective, the two languages had, during the medieval period, (i) come in contact with the system inherited directly from Vulgar Latin in which there were two forms of address distinguished pragmatically for a single interlocutor: (Sp./Pt.) tú/tu and vos/vós; (ii) included a new nominal form Vuestra Merced/Vossa mercê; and finally (iii) undergone a desemanticization of the old address form for deference (vos/vós). ${ }^{4}$ Unlike Spanish, Portuguese did not experience a shift of $v o$ s to the realm of intimacy with a consequent loss of the $t u$ / vós opposition. Though it deteriorated pragmatically after the inclusion of Vossa mercê, vós continued to be a form of distancing throughout the medieval period (Domingos 2001; Marcotulio 2014), surviving until the 18th century (at least) as an address form of non-solidarity, when it then underwent a process towards becoming "archaic", in the terms of Cintra (1972) and Faraco (1996), at least in most varieties of Portuguese including the standard forms. The shift from one level to the other that occurs in Portuguese takes place based on the você form (resulting from the grammaticalization of Vossa mercê), which began to occupy the sphere of intimacy, dissolving the old pragmatic tu/você opposition. If, in BP, there is você and $t u$ and, in Sp. voseo, there is vos and tú, what do these two systems have in common?

It is necessary to have in mind that the processes of implementing forms of distance within the realm of intimacy, triggered initially by issues of a pragmatic nature, can lead to similar repercussions on the grammatical level, specifically with respect to the forms from one paradigm or another that have been established in the address system. What do we mean by this?

There is no single type of voseo used across all of Hispanic America. This is due to regional and sociopragmatic differences and the various possible combinations in verbal-pronominal terms - voseante pronominal forms combined with tuteante verbal forms (vos cantas) and vice versa (tu cantás). However, as

4 The later developments in the various subsystems in Hispanic America are very complex and will not be addressed here due to the specific objective of this chapter. For more details, see, among others, Hummel et al. (2010), and, more recently, Bertolotti (2015). 
Bertolotti (2015: 31) points out, "in the voseante modalities, the integration of the vos paradigm with the object pronouns and original possessives from the tú paradigm" is very general. In BP, the same occurs: você is more general as a subject and as a prepositional complement (prep. + você), while the forms from the $t u$ paradigm have been kept as object pronouns (te in the accusative and dative). The difference is in the possessive, since seu - as well as inflections - from the voce paradigm predominates, not the $t u$ forms (teu and inflections).

Bertolotti's study (2015) is very revealing in showing the complexities of the Spanish that arrived in America over the centuries. The author claims that forms of address referred to as pure and mixed forms coexisted. Table 4 summarizes the distinction: the pure forms for each of the existing paradigms are in lines 1, 2 and 3, and the forms mixed "by combining elements from lines 1 and 2 or 1 and 3" respectively, are in lines 4 and 5.

Table 4: Pure and mixed pronominal and verbal forms organized according to their paradigm (adapted from Bertolotti 2015: 152).

\begin{tabular}{|c|c|c|c|c|c|}
\hline & Subject & $\begin{array}{l}\text { Clitic } \\
\text { complement }\end{array}$ & $\begin{array}{l}\text { Complement } \\
\text { of preposition }\end{array}$ & Possessive & Verb \\
\hline 1. & vos & os & vos & vuestro/a(s) & $\begin{array}{l}\text { voseante (diphthong or } \\
\text { monophthong, with or } \\
\text { without ending in }-d \text { ) }\end{array}$ \\
\hline 2. & tú & te & ti & tu/tuyo/a(s) & tuteante \\
\hline 3. & $\begin{array}{l}\text { usted }<\text { vuestra } \\
\text { merced }\end{array}$ & lo/la/le & $\begin{array}{l}\text { usted }<\text { vuestra } \\
\text { merced }\end{array}$ & su/suyo/a(s) & $\begin{array}{l}\text { in morphological third } \\
\text { person }\end{array}$ \\
\hline 4. & vos & te & $\operatorname{vos} / t i$ & tu/tuyo/a(s) & voseante or tuteante \\
\hline 5. & usted & os & usted & vuestro & $\begin{array}{l}\text { voseante or in } \\
\text { morphological third } \\
\text { person }\end{array}$ \\
\hline
\end{tabular}

Bertolotti (2015) attempts to provide an explanation for these new so-called mixed forms (for lack of a better term). The author claims that the mix of forms in line 4 of Table 3 does not indicate a fusion of paradigms because of the loss of contrast between vos and tú, as argued by Fontanella de Weinberg (1992: 185). One of the reasons is the fact that the mix of forms found in the documents is prior to the desemanticization of vos as an address term of trust and deference. Another possible explanation for the establishment of the clitic (te) and the possessive tu/ tuyo( $a(s)$ in the vos paradigm (line 4) could be systemic in order to distinguish the singular forms from the plural. However, we consider these arguments to be insufficient in providing an explanation. 
The pragmatic and structural motivations to explain the development of the mixed voseo paradigm in Hispanic America and the você paradigm in BP are fundamental for understanding the processes of change. Nevertheless, our intention here is not to present an explanatory proposal for the phenomenon. For now, we limit ourselves to examining whether the identical positions of the mix of forms in both paradigms are truly coincidental.

What stands out is that in the two paradigms ${ }^{5}$ (BP and Sp. voseo) the differences almost always occur in the same place: você/vos is in the role of subject and prepositional complement (prep. + você/prep. + vos), but te/te is a nonprepositional complement (see Table 5). This non-coincidence occurs in the possessives: seu/sua/a(s) in BP and tu/tuyo/a(s) in Sp. voseo.

Table 5: Comparison of BP and Hispanic American voseo: coinciding positions in the second person singular system (2SG).

\begin{tabular}{lllll}
\hline & Subject & $\begin{array}{l}\text { Non-prepositional } \\
\text { complement }\end{array}$ & $\begin{array}{l}\text { Prepositional } \\
\text { complement }\end{array}$ & Possessive \\
\hline PB & você & $t e$ & prep. + você & seu/sua/a(s) \\
\hline Hispanic voseo & vos & $t e$ & prep. +vos/ti & $t u / t u y o / a(s)$ \\
\hline
\end{tabular}

In sum, while Brazilian Portuguese does not yet have a complete descriptive mapping of the current status of its pronominal address system, unlike Hispanic America, ${ }^{6}$ it is undeniable that você generalized in BP as a subject pronoun together with a more limited presence of $t u$ in some geographical areas. In the same way as occurs in various Hispanic America types of voseo, specific studies on BP show that the system based on você seems to have kept, in some regions in Brazil, the clitic te (from the tu paradigm) as a direct and indirect object (accusative and dative, respectively), even when the speaker/writer uses você in subject position (Oliveira 2014; Souza 2014). The prepositional complements also seem to favor the forms from the você paradigm (prep. + você) and not those from the $t u$ paradigm (prep. + ti), similarly to what occurs in the Hispanic voseante system, in which "prep. + vos" is more frequent than "prep. $+t i$ ".

We therefore intend to show in this chapter that the symmetrical and uniform systems (tu-te-ti-contigo-teu) or (você-o/a-lhe- prep. + você-seu) are virtually unused in Brazilian Portuguese. We claim that the introduction of você in the

5 We point out the most frequent forms and not the only possibilities, as we will show in the description of the results for BP.

6 See also Carricaburo (1997: 12-13), Fontanella de Weinberg (1992: 140), Bertolotti (2015: 71), among others. 
pronominal system in BP did not occur in the same way in the entire pronominal paradigm. Therefore, we aim to examine the rate at which the changes in the development of the address systems in BP took place. To this end, we will map the results from two Brazilian regions (Southeast and Northeast), representing the relation between subject (nominative) position and the other positions (accusative, dative, oblique and genitive) based on data from letters written by Brazilians at the end of the 19th century and over the course of the 20th century. The intention, as Conde Silvestre (2007: 150) claims, is to determine the stages of the changes in the pronominal structure in the linguistic system, determining the changes that took place more quickly or more slowly.

\section{The corpus}

To historically rebuild the subsystems of address in Brazil, following the spread of você between the end of the 19th century and over the course of the 20th century, we used part of the National PHBP corpus - Project for the History of Brazilian Portuguese. The partial studies we used analyzed a total of 1,332 personal letters written by people who belonged to different groups of prominent and non-prominent families. The letters from the Southeastern ${ }^{7}$ region total 522: 366 from Rio de Janeiro (1870-1979); 89 from Minas Gerais (1850-1989); and 67 from São Paulo (1870-1930). For the Northeast, ${ }^{8}$ the material is slightly broader in scope. There are 810 letters: 383 from Bahia (1810-1990); 123 from Pernambuco (1869-1969); and 304 from Rio Grande do Norte (1916-1925). Although the distribution is not completely balanced, the sample allows us to outline a broad and diversified profile of the community studied. Since the study of forms of address depends on interactive situations, we chose letters of a rather personal nature, such as messages exchanged between family members, friends and couples.

In order to offer an overview that could serve as a foundation for the representation of Brazilian Portuguese, our choice of the two regions analyzed - the Southeast and Northeast - was not random. These regions currently represent $70 \%$ of the population of the country (ESTIMATIVAS 2015). Due to the coloniza-

7 We will use the following abbreviations for the Southeastern states: RJ (Rio de Janeiro), MG (Minas Gerais) and SP (São Paulo).

8 Similarly, we will use BA (Bahia), PE (Pernambuco) and RN (Rio Grande do Norte) for the Northeastern states. 
tion process, the highest population concentration is in coastal areas, particularly in the Southeastern region and in the so-called Northeastern Zona da Mata. ${ }^{9}$ The Southeastern region, which is the most populous, has more than 85 million inhabitants (42\%) and the Northeastern region has more than 56 million (28\%). The Southeastern region also has the three most populous metropolitan areas in the country according to the last census in 2010 (São Paulo-SP, with 21,242,939 inhabitants; Rio de Janeiro-RJ, in second place, with 12,330,186; and Belo Horizonte-MG, third, with 5,873,841 inhabitants). Salvador-BA and Recife-PE, in the Northeastern region, are, respectively, the seventh and eighth most populous regions, while Natal-RN is in 19th place (Demografia 2018).

If we go back to the time when the first letters analyzed here were written (1870), we can determine that the two regions studied were the most populous, though with an inverse population density. Some areas of the Northeast, such as Pernambuco, had a higher number of inhabitants than the most populous state in Brazil today (São Paulo). Consequently, the first demographic census in Brazil, carried out in 1872, during the imperial period, indicated that the Northeastern region was the most populous in the country. Brazil had 9,930,478 inhabitants and four of the eight most populous provinces were in the Northeast. The two regions together contained $87.2 \%$ of the Brazilian population.

Map 2 illustrates the growth of the main Brazilian capitals from 1872 (Censo demográfico do Brasil from 1872, 2018) until the 2000s. The shading in the colored circles, from lighter to darker shades, shows the locations that had almost 300 thousand inhabitants at the end of the 19th century. In this case, they are São Paulo-SP, Rio de Janeiro-RJ, Salvador-BA and Recife-PE. The size of the circle indicates the size of the population concentration over the course of more than 100 years.

In conclusion, this brief overview of the Brazilian demographics aims to show that the areas selected are representative because they concentrate the largest part of the country's population in the course of more than a century. However, we cannot ignore that we are analyzing texts written by a population with a low literacy rate from the beginning (in the 19th century, less than $40 \%$ of the population was literate). This means that the results obtained can only be indicators of the path of change in progress.

9 This refers to a narrow, coastal plain that runs along the Northeastern edge of the country and has a tropical climate. 


\section{Crescimento das capitais}

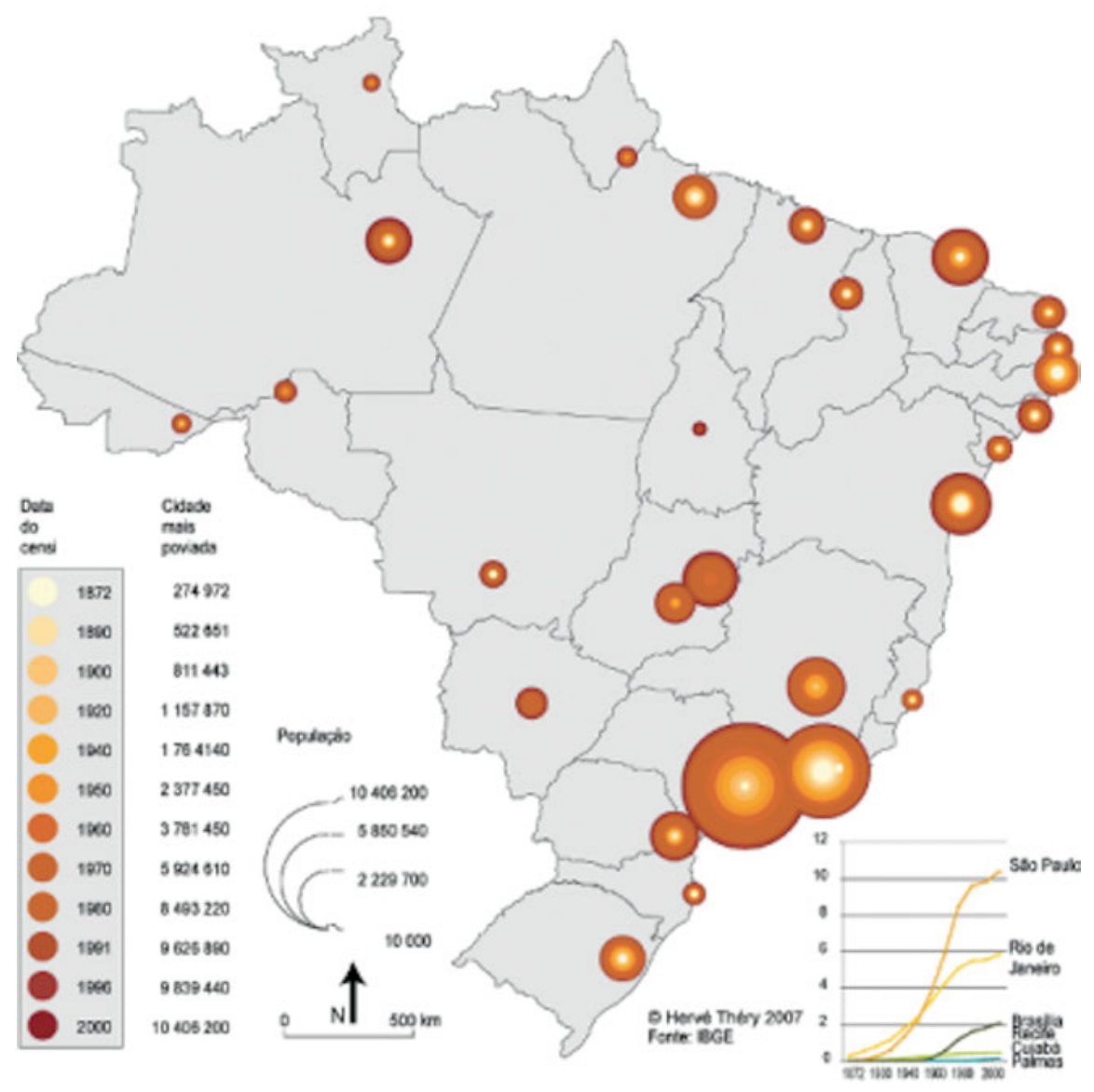

Map 2: Growth of the main Brazilian capitals from 1872 to 2000 (source: Wikimedia Commons, the free media repository. 25 Feb 2014, 21 Sept. 2018, https://commons.wikimedia.org/w/ index.php?title=File:ARCHELLA_E_THERY_Img_07.png\&oldid=117330012). 


\section{The subject position}

\subsection{Você and $t u$ in subject position in letters from the 19th and 20th centuries: Southeastern region}

Synchronic studies based on oral data point out that the Southeastern region is not homogeneous in its use of subsystems of address in subject position. On the one hand, there is a mixed subsystem (você $\sim t u)$ in the more coastal area, represented here by Rio de Janeiro (Paredes 1996; Santos 2012). On the other hand, there is the almost absolute predominance of você and its variants (ocê, cê, etc.) in the more interior states, such as São Paulo and Minas Gerais (Scherre et al. 2015; Peres 2006: 131; Mota 2008).

The establishment of this current system in the Southeastern region needs to be mapped in socio-historical terms. The various analyses carried out, based on the letters produced by residents in Rio de Janeiro, São Paulo and Minas Gerais, between the end of the 19th century and over the course of the 20th century, show that the presence of the two variant forms is very old. In the documents analyzed, we can clearly see senders using only você, only $t u$, or the two forms in variation in the same letter for their recipients. Graph 1 brings together the results from these three locations in the Southeastern region, adapted from Lopes \& Souza (2018), Rumeu, Cruz \& Cardos (2018) and Balsalobre \& Monte (2018).

The graph presents the historical behavior of the use of você in relation to the tu pronoun in subject position in three locations in the Southeastern region. ${ }^{10}$ As we mentioned, the sample of letters analyzed here is not entirely comparable if we take into account, for example, that the sample of letters for São Paulo only goes up to 1930. Nevertheless, we can still comment on the dissemination of você in subject position in the letters from this region.

Although the path of each line in Graph 1 is different, we can see that from the end of the 19th century (1870-1879) until the mid-20th century - approximately 1940 - the use of second person forms of address in the letters from Rio de Janeiro and São Paulo was equivalent, as distinct from what was observed in the letters from Minas Gerais. While in the former two regions você address was very little used more so in the letters from Rio de Janeiro ${ }^{11}$ than in those from São Paulo - the letters

10 Since Graph 1 only shows the results of você, the data regarding tu can be understood in a complementary way. For example, $31 \%$ of você means that there is a $69 \%$ rate of $t u$ at the same time. 11 The historical explanations for the more frequent use of $t u$ in Rio de Janeiro are very complex and are usually associated with the establishment of the Portuguese Court in the 19th century and the constant arrival of Portuguese to the then capital of the country. 


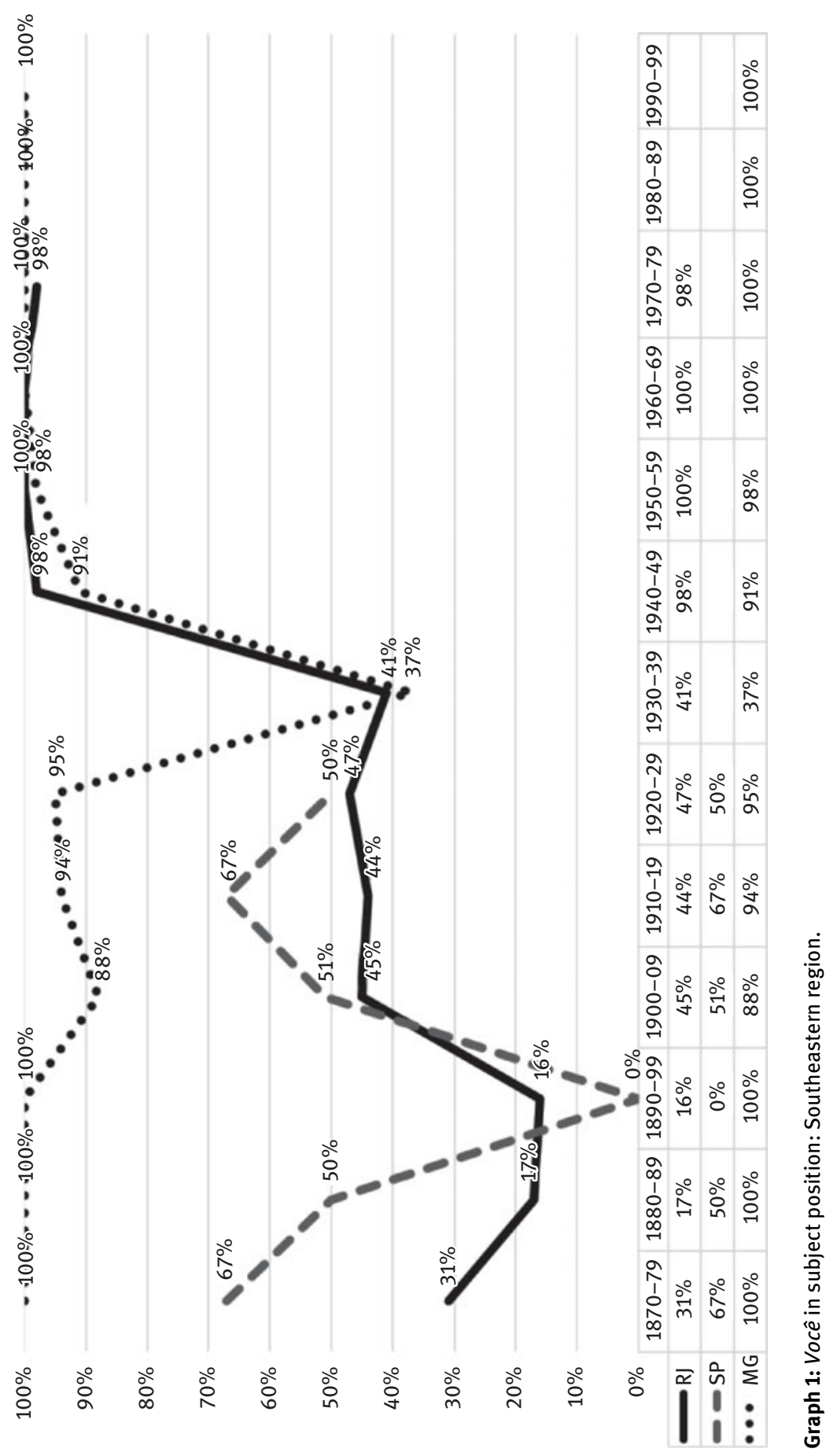


from the Minas Gerais writers indicate an almost exclusive use of você with rates very close to $100 \%$. The point of intersection seems to be in the years 1930-40, in which the curves of Rio de Janeiro and Minas Gerais overlap with low rates of você in the two locations and they continue to overlap from then on, revealing, however, a generalization of você in the two locations with frequencies closer to $100 \%$.

Lopes \& Souza (2018) clearly point out the rate at which você spread by identifying different behaviors of the innovative pronominal form over time. At the end of the 19th century, the use of você was more frequent than $t u$ in asymmetrical and less intimate relations between writers, maintaining the politeness features from vossa mercê. The use of você served as an attenuation strategy in favor of linguistic politeness and for marking greater distance, which guaranteed a less invasive tone in the interaction, as shown in example (5).

(5) Peço-te pois intenderes com elle esperando qelleasuma ao meo pedido, pelo $\underline{q}$ mui agradecido. Podia tambem escrever a seoPae, e Dr J. P. porem entendo não ser necessario só basta q você si interessou. [1st half of the 20th century, RJ]

[I] ask-you since to-understand with him waiting that he accept to my request, for that very grateful. Could also to-write to your Father, and Dr. J.P. though [I] understand not to-be necessary only enough that you yourself interested.

'I ask that you come to an understanding with him hoping that he accepts my request, for which I am very grateful. I could also write to your father, and Dr. J.P., though I understand that it is not necessary, only that you are interested'

In example (5), we see a motivated use of você. The sender gives an indirect order in a request, which favors the use of an attenuating address form. In the letter, in which (null) tu predominates almost categorically, the intruder você is not a pronominal variant, but a form of address that minimizes the request made. The uncle claims that it was not necessary to make the request to the father of the receiver, who was an important politician, since he was interested in solving the problem in question.

At the beginning of the 20th century, the use of você could still mark a certain deference, mainly in letters by women, as in example (6). Among men, even though there was asymmetry between them, $t u$ prevailed, which was not common or adequate for women, as illustrated in example (7).

(6) Afonsinho Saude te desejo e a todos os seus. Vamos indo sem novidade, E. tem melhorado da tosse. Vossé querendo me favoreçer, compra para vossé. Não quero te caçetear, dê um beijo nos pequenos e com M. aceite um abraço 
saudoso de Sua tia e ama cinçera A. Não repare a letra q estou muito sem vista. (aunt-nephew) [1st half of the 20th century, RS]

Afonsinho Health you [I]wish and to all of yours. [We]go going without news, E. has improved of-the cough. You wanting me to favor, buy for you. Not [I]want you upset, give a kiss in-the little-ones and with M. accept a hug missing of Your aunt and love sincere A. Not notice the letter that I am very much without seeing

'Afonsinho I wish health to you and yours. We have had no news. E.'s cough has improved. You are trying to help me, buy it for yourself. I don't want to upset you, give a kiss to the little ones and with M. accept a beloved hug from your aunt and sincere love A. Ignore my writing since my sight has been greatly lacking'

(7) Pela tua carta de $1{ }^{\circ}$ vejo os motivos que tens para não escreveres todos os dias o que me pareciam justos. Escrevas quando puderes, ao menos uma vez por semana. (father-son) [2nd half of the 19th century, RJ]

For your letter of 1st [I] see the motives that [you]have to not [you]write all the days the that me seem fair. [You]write when [you]can, at least one time a week.

'From your letter, I can already see the reasons you have for not writing every day, which seems fair to me. You write when you can, at least once a week'

Gradually, the você form started to be used in the same functional contexts as $t u$, including more informal and intimate contexts - see example (8). The você form also began to take the place of $t u$ in symmetrical relations: a functional space that was assumed gradually.

(8) Pode você bem calcular o vasio infinito que se fez na minha vida. [1st half of the 20th century, RJ]

Can you well to-calculate the empty infinite that is done in my life

'You can easily calculate the infinite void that you have left in my life'

The spread of você over the course of the 20th century is related mainly to the dissemination of its use in egalitarian relations, as in example (9). At the end of the 20th century, the você pronoun replaced the older strategy with its expansion to contexts typical of $t u$. As a strategy of neutral reference, the você pronoun became a versatile strategy for the new social roles of contemporary societies. 
(9) São três e meia da manhã de domingo acabei de chegar do samba e ao subir me entregaram sua carta que em poucas linhas disse muitas coisas bonitas coisas que você sabe que sinto mas que não consigo passar para o papel. [2nd half of the 20th century, RJ]

Are three and half of morning of Sunday [I]ended of to-arrive of-the samba and to to-go up me [they]delivered your letter that in few lines said many things pretty things that you know that [I]feel but that no [I]can to-pass to the paper

'It is three-thirty on Sunday morning and I have just arrived from the samba and when I went up, they gave me your letter, which in a few lines said many things, beautiful things that you know that I feel, but I cannot put on paper'

In conclusion, the results obtained from the letters written in the Southeastern region show that the spread of você took place mainly from the mid-20th century on. With rates of frequency fluctuating a great deal in each location, we determined the presence of $t u$ at the end of the 19th century and at the beginning of the 20th century, mainly in Rio de Janeiro, due to the strong movement of Lusitanian influence that occurred upon the arrival of the Portuguese Court in the beginning of the 19th century and the constant arrival of the Portuguese until the 1940s. The letters from Minas Gerais reveal very consistent behavior over the course of the entire period analyzed, with widespread and regular use of você.

\subsection{Você and tu in subject position in letters from the 19th and 20th centuries: Northeastern region}

The situation in the Northeastern region is very complex, with variation between você and $t u$ in most of the states. The regional distinctions in the Northeast are limited to the presence or absence of agreement with the tu pronoun, which does not exceed 40\%, according to Scherre et al. (2015). As in the Southeast, there are areas with predominant use of você, as is the case of the capital of Bahia (Salvador). In the rest of the state, and in the others analyzed (Pernambuco and Rio Grande do Norte) the subsystem is mixed: você $\sim$ tu (Lucchesi et al. 2009: 83-95; Almeida 2012; Amor Divino 2008; Sette 1980: 148-168; Coelho da Silva 2015).

The results from letters written at the end of the 19th century and over the course of the 20th century are presented in the Graph 2. They were taken from the studies by Andrade, Oliveira \& Carneiro (2018); Gomes \& Lopes (2018) and Moura \& Martins (2018). 


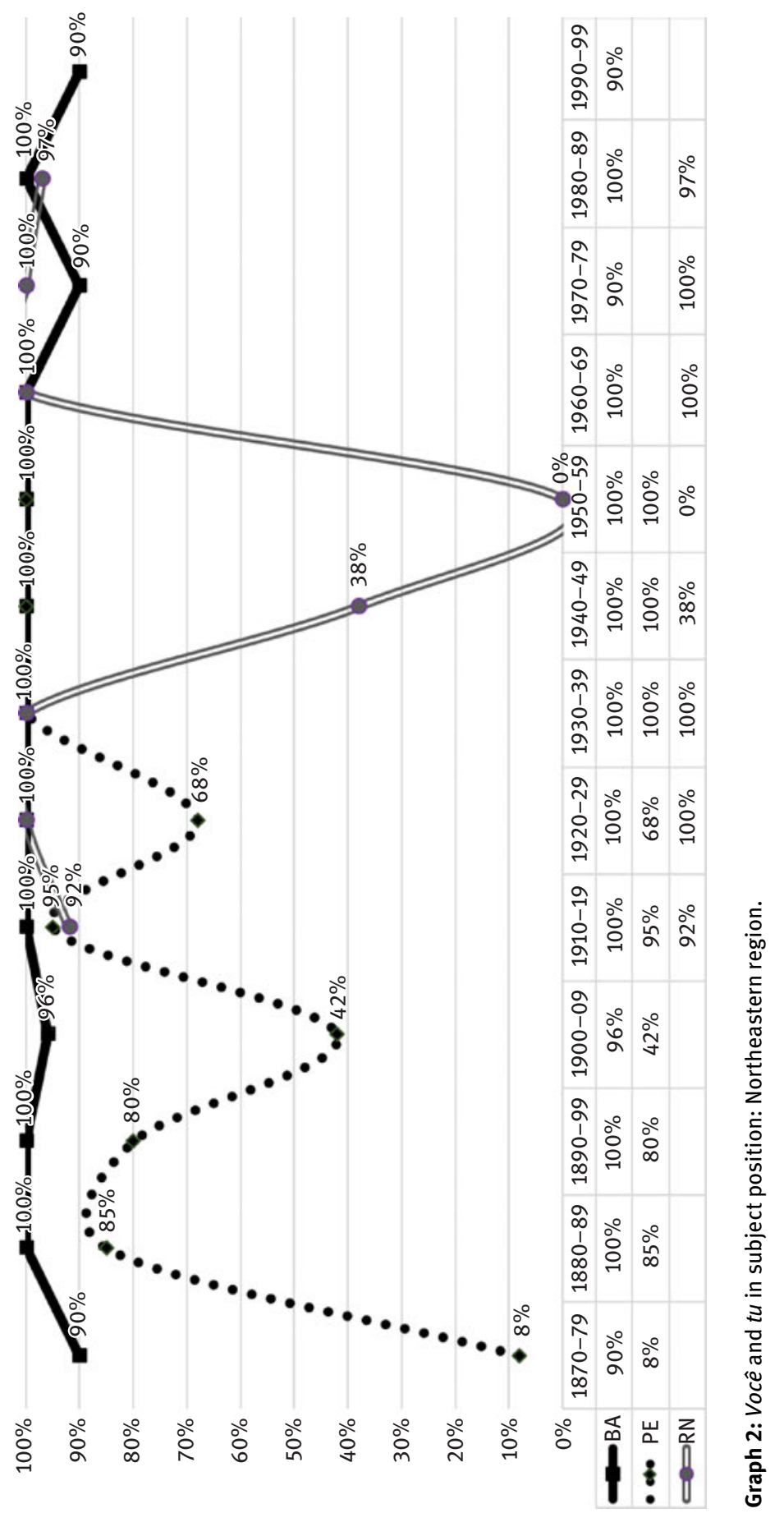


As in Graph 1 representing the Southeast, Graph 2 reveals the spread of você in the Northeast starting mainly in the second half of the 20th century. In comparative terms, the behavior of the three Northeastern locations is not the same, with areas of strong variation between $t u$ and você, as observed in Pernambuco, and areas of stability, such as in the letters from Bahia. The results from Rio Grande do Norte span practically the entire 20th century. As seen in the graph of the Southeastern region, here we also observe an abrupt and rapid decline in the 1950s. Nevertheless, Graph 2 with data from the letters from the Northeast indicates greater stability in the use of você over the course of the period analyzed when compared to what was observed in the Southeast.

Finally, in the written samples from the two regions, in general, a gradual loss of the tu pronoun took place in favor of the new grammaticalized você form. This loss was observed mostly in the first half of the 20th century. The use of these forms, however, presents a quantitative distribution in geographical terms. As Lopes et al. (2017) argue, the results point to the multifunctional behavior of você, since the new pronominal form loses the semantics of power, preserved from the original vossa mercê, moving into the space of solidarity.

Map 3 illustrates the changes in the use of você at three moments in time across the Brazilian territory as a whole, and demonstrates the gradual and continuous generalization of você in the main areas of the two regions studied. The colour scale used goes from black to light gray: the darker the color, the greater the use of $t u$, and the lighter the color, the higher the rates of use of the você pronoun.

End of the 19th century

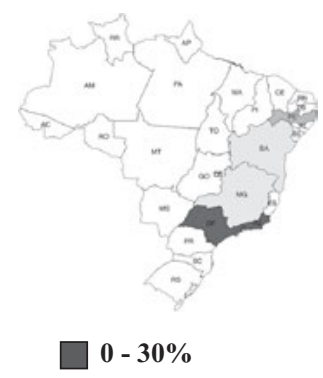

Firstquarter of the 20th century

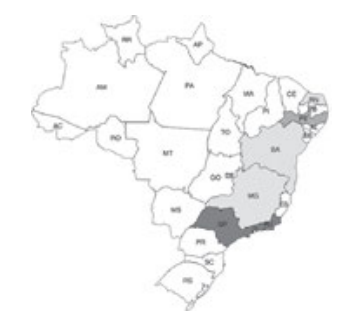

$31 \%-50 \%$
Second half of the 20th century

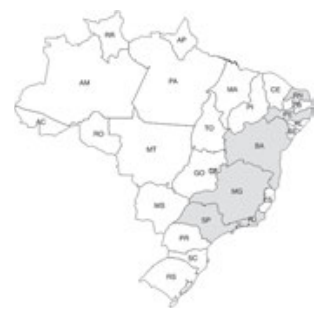

$\square 0 \%-100 \%$

Map 3: The second person subject position in BP: rates of use of você at three moments in time.

The maps illustrate the dissemination of você in relation to tu in subject position in the recent history of BP and indicate its expansion into the Southeast and Northeast regions. We observe the rise of the frequencies of você between the 
end of the 19th century and the first quarter of the 20th century, spreading with greater intensity in the second half of the 20th century.

To a certain extent, the subsystems of address seen from a diachronic perspective correspond to the current existing subsystems in BP, such as those outlined by Scherre et al. (2009, 2015). The letters from writers in Bahia - predominantly a você subsystem - reveal a consistent use of this form over the course of the period analyzed. This behavior is very similar to that seen in Minas Gerais in Graph 1. The results from Pernambuco - currently a você/tu subsystem - are similar to those seen in Rio de Janeiro, with alternation between the two variant forms until the mid-20th century.

In addition to the general results from each location, it is also worth separately investigating the data found in the letters in which writers use the você form exclusively in subject position. To this end, we consider three possibilities as the criteria for analyzing the data:

a) exclusive tu: the cases in which the sender used only the tu pronoun (null or overt) as a subject in their letters, as in example (10):

(10) $\boldsymbol{t} \boldsymbol{u}$ resolverás como entenderes, meu querido anjo, e, eu cegamente cumprirei o que $\boldsymbol{t} \boldsymbol{u}$ ordenares. [1st half of the 19th century, RJ]

you will resolve as [you]understand, my dear angel, and, I blindly willfulfill what you order

'you will sort it out the way you think is best, my dear angel, and, I will blindly do what you wish'

b) exclusive você: the cases in which the sender used only você as a subject in the letters analyzed:

(11) Você não imagina como Marília está levada. [2nd half of the 20th century, $\mathrm{MG}]$

You not imagine as Marília is naughty

'You cannot believe how naughty Marília is'

c) mixed tu/você: the cases in which the sender used both forms in the same letter in subject position:

(12) $\boldsymbol{T} \boldsymbol{u}$ não deves pensar em bobagens ... você sabe perfeitamente que só ati é que eu amo. [1st half of the 20th century, RJ] 
You not should to-think in nonsense ... you know perfectly that only to-you that I love.

'You should not think about nonsense (...) you know perfectly well that I only love you'

If the writer used você in the role of subject, what forms can be found in the other grammatical relations? Are there differences across regions? Which forms constitute the Brazilian voceamento system? We will discuss these questions in the following section.

\section{The behavior of other second person functions in Brazilian letters from the 19th and 20th centuries: accusative, dative, oblique and genitive}

The objective of this section is to present the consequences of the spread of você on second person verbal complement relations (accusative, dative and oblique), traditionally known as "oblique pronouns" (tonic and atonic), and on possessive pronouns (genitive relation). Although there is not complete correspondence between the Portuguese and Latin pronominal forms, considering the variation of case, we will adopt the following terminology for the verbal complements and the second person possessives:

a. accusative (AC) - complement or direct object (DO);

b. dative (DAT) - complement or indirect object (IO), realized as a clitic or as a prepositional phrase. In this latter case, there is also the possibility of cliticization using lhe;

c. oblique $(O B L)$ - prepositional phrase complement, which cannot be substituted by a clitic;

d. genitive (GEN) - complement or nominal adjunct, represented by a possessive pronoun.

If, as we have seen, the você pronoun was incorporated over time into the BP address system as a variant of the older tu pronoun, what happened in the other syntactic positions? Did the forms from the você paradigm start being used in all of the syntactic functions at the same rate that it was used in subject position? After the inclusion of você, how did the voceante system in BP develop in the rest of the pronominal system? 


\subsection{The variants of second person accusative complements in Brazilian letters from the 19th and 20th centuries}

We consider accusatives to be the second person pronominal forms that take on the role of direct object. In the traditional perspective of maintaining the same paradigm or "uniformity of address", the original second person form in the accusative case would only be the clitic te. However, upon the inclusion of você in the system, there are other variants in BP that belong to the você paradigm. In this case, they are the você form itself and the clitics from this paradigm, $o / a$ and lhe.

The variation of accusative forms associated with the você paradigm is more diversified due to the origin of this form and to the alterations within the pronominal paradigm. Resulting from a nominal expression (vossa mercê), which required the verb to be in the third person singular, the você form kept some of the morphosyntactic properties of its original form - even though its semantic-discursive interpretation became a second person reference. Unlike the original second person pronoun $t u$, the grammaticalized form (você) can appear in all of the syntactic positions without altering its form. Consequently, the você pronoun brings to the second person pronominal system forms originally from the third person system.

In the accusative function, the following can occur: the tonic form você, the original third person clitic $-o(s) / a(s)$ - in addition to the third person dative clitic (lhe), which also began to function as an accusative in reference to the second person.

In sum, if there was symmetry or a maintenance of forms from the same paradigm, the clitic te (example (13)) would be used with the tu pronoun in subject position. However, if the writer addresses their interlocutor with você, in this case, they would use the forms corresponding to the você paradigm, originally in the third person: lexical pronoun você (example (14)), the clitics o/a (example (15)), the clitic lhe (example (16)) and, even the null object (example (17)), which is very rare in this role.

(13) No momento mais triste de minha vida te encontrei. [1st half of the 20th century, RJ]

In-the moment most sad of my life you [I]found

'At the saddest moment in my life, I found you'

(14) a nave que você pilota há de erguer voo seguro elevando você. [1st half of the 20th century, MG]

the craft that you pilot has to take flight safe elevating you to the heights

'the craft that you pilot has to take flight safely lifting you high up' 
(15) Percizava vello para sentar as couzas milhor. [2nd half of the 19th century, BA] Needed see-you to sit the things better 'I had to see you to settle things better'

(16) Com affecto lhe abraço e sou sua irmã. [2nd half of the 19th century, RJ] With affection you [I]hug and [I]am your sister 'With affection, I hug you and I am your sister'

(17) tu sabes como me sinto, cada vez mais cego, e cada vez querendo $\emptyset$ amar mais. [1st half of the 20th century, RJ]

you know how me [I]feel, each time more blind, and each time wanting $\emptyset$ to-love more

'you know how I feel, increasingly blind, and increasingly wanting to love you more'

Table 6 presents the distribution of the variant accusative forms in the personal letters from the locations studied in the two regions.

Table 6: Distribution of second person accusative variants in Brazilian letters by region (19th-20th centuries).

\begin{tabular}{llllllll}
\hline Accusative & & te & voce & lhe & o/a & $\varnothing$ & Total \\
\hline Southeast & Rio de & $337 / 433$ & $29 / 433$ & $17 / 433$ & $40 / 433$ & $10 / 433$ & $443 / 829$ \\
& Janeiro (RJ) & $78 \%$ & $7 \%$ & $4 \%$ & $9 \%$ & $2 \%$ & $53 \%$ \\
\cline { 2 - 7 } & Minas & $21 / 42$ & $3 / 42$ & $3 / 42$ & $15 / 42$ & $42 / 829$ \\
& Gerais (MG) & $50 \%$ & $7 \%$ & $7 \%$ & $35 \%$ & $5 \%$ \\
\cline { 2 - 7 } & São Paulo & $15 / 34$ & $2 / 34$ & $6 / 34$ & $11 / 34$ & $34 / 829$ \\
& (SP) & $44 \%$ & $6 \%$ & $18 \%$ & $32 \%$ & $4 \%$ \\
\hline \multirow{5}{*}{ Northeast } & Bahia (BA) & $7 / 62$ & $1 / 62$ & $28 / 62$ & $26 / 62$ & $62 / 829$ \\
& & $9 \%$ & $1 \%$ & $38 \%$ & $35 \%$ & $7 \%$ \\
\hline & Pernambuco & $14 / 45$ & $6 / 45$ & $6 / 45$ & $19 / 45$ & $45 / 829$ \\
& (PE) & $31 \%$ & $13 \%$ & $14 \%$ & $42 \%$ & & $5 \%$ \\
\cline { 2 - 8 } & Rio Grande & $151 / 213$ & $18 / 213$ & $40 / 213$ & $4 / 213$ & & $213 / 829$ \\
& do Norte (RN) & $71 \%$ & $8 \%$ & $19 \%$ & $02 \%$ & & $25 \%$ \\
\hline \multirow{2}{*}{ Total } & & $530 / 829$ & $59 / 829$ & $100 / 829$ & $127 / 829$ & $10 / 829$ & 829 \\
& & $64 \%$ & $7 \%$ & $12 \%$ & $15 \%$ & $1 \%$ & \\
\hline
\end{tabular}


In terms of the overall results, the clitic te was the most frequent accusative strategy in the sample, in 530 of a total of 829 occurrences (approximately 65\% of the corpus). The second and third most frequent strategies, respectively, were well under $20 \%$. They are, in this case, the accusative clitic o/ $a$ with $15 \%$ and lhe with $12 \%$.

Considering the partial results, by region, te predominated in the Southeastern region and in one Northeastern state (RN). In the others, there was more frequent use of specific forms from the você paradigm, as in Bahia, in which lhe (38\%) and o/ a (35\%) were more frequent, and in Pernambuco, with 42\% using $o / a$. It is worth noting as well that in none of the locations studied in our analysis did the você form, used itself in the accusative role, register a frequency higher than $10 \%$. In the majority of the states, the accusative você was the third most used strategy, amounting to only a few occurrences.

We must also mention some rarer occurrences, as in the case of the zero identified in the letters from Rio de Janeiro. Most of the time, the zero accusative occurs in coordinated structures of the type (te estima e Ø adora 'esteem you and adore Ø).

In order for us to determine how the voceante paradigm developed in BP, we will now analyze the variant forms of the accusative that occurred only when the writer used the voce pronoun as the exclusive subject in their letters. In principle, if the system of address were symmetrical, we would expect the accusative clitic te to occur only in letters with the tu subject. Similarly, accusative forms from the você paradigm (você/lhe/o,a) would occur with the você subject. Table 7 sets out the results.

Table 7: Distribution of second person accusative variants in letters with the você subject, by Brazilian region (19th-20th centuries).

\begin{tabular}{|c|c|c|c|c|c|c|}
\hline \multirow[t]{2}{*}{ Accusative } & & \multicolumn{5}{|c|}{ 2P Accusative forms and the use of the você subject } \\
\hline & & te & você & lhe & $0 / a$ & $\varnothing$ \\
\hline \multirow[t]{6}{*}{ Southeast } & Rio de Janeiro & $60 / 118$ & $19 / 118$ & $10 / 118$ & $26 / 118$ & $3 / 118$ \\
\hline & & $51 \%$ & $16 \%$ & $9 \%$ & $22 \%$ & $2 \%$ \\
\hline & Minas Gerais & $15 / 29$ & $5 / 29$ & & $9 / 29$ & \\
\hline & & $51 \%$ & $17 \%$ & & $31 \%$ & \\
\hline & São Paulo & $1 / 3$ & $1 / 3$ & & $1 / 3$ & \\
\hline & & $33.3 \%$ & $33.3 \%$ & & $33.3 \%$ & \\
\hline \multirow[t]{6}{*}{ Northeast } & Bahia & $2 / 47$ & $1 / 47$ & $24 / 47$ & $20 / 47$ & \\
\hline & & $4 \%$ & $2 \%$ & $51 \%$ & $43 \%$ & \\
\hline & Pernambuco & $1 / 29$ & $5 / 29$ & $6 / 29$ & $17 / 29$ & \\
\hline & & $3 \%$ & $17 \%$ & $21 \%$ & $59 \%$ & \\
\hline & Rio Grande do Norte & & & $3 / 3$ & & \\
\hline & & & & $100 \%$ & & \\
\hline \multirow[t]{2}{*}{ Total } & & $79 / 229$ & $31 / 229$ & $43 / 229$ & 73 & $3 / 229$ \\
\hline & & $35 \%$ & $13 \%$ & $19 \%$ & $32 \%$ & $1 \%$ \\
\hline
\end{tabular}



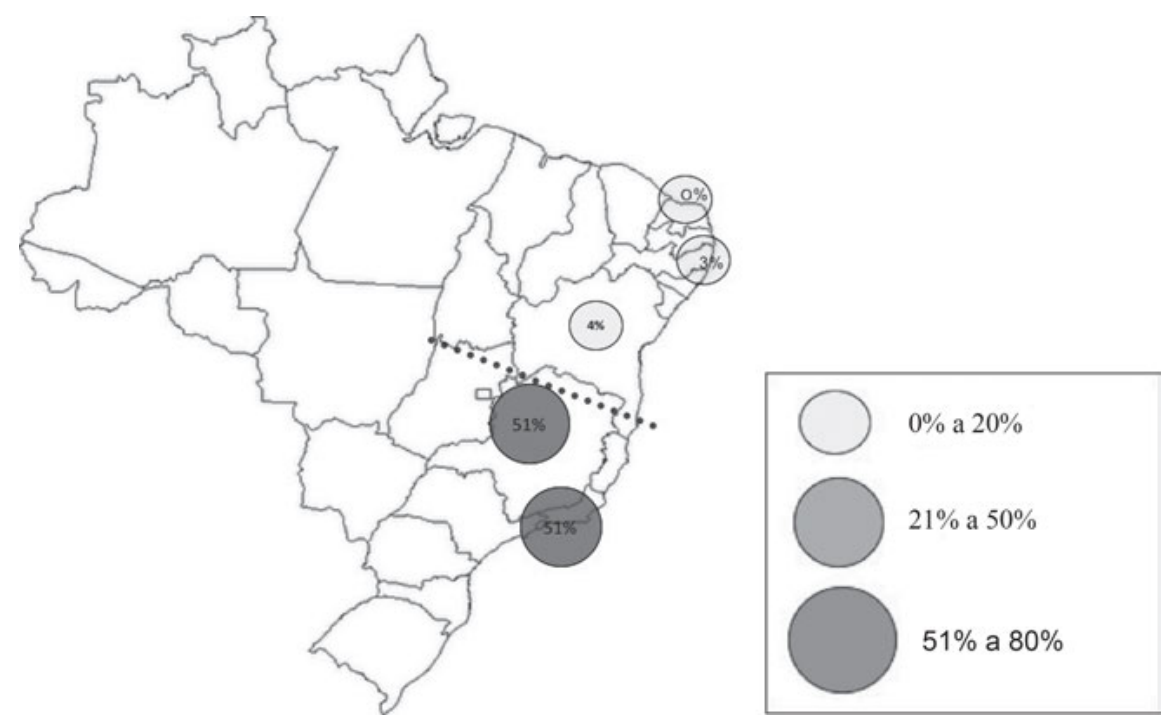

Map 4: The clitic accusative te in letters with the você subject (19th-20th centuries) ${ }^{12}$.

As can be seen in Table 7, the results obtained based on cross-referencing the exclusive use of você in subject position and the accusative second person forms reveal that the clitic $t e$ (from the $t u$ paradigm) was used as the most frequent strategy, at 35\%. This predominance of te did not occur in both regions: only in the letters from the Southeast were there rates over 50\% in Rio de Janeiro and Minas Gerais. In the Northeastern region, the behavior differed, since the forms belonging to the você paradigm predominated with differences regarding the frequencies of each strategy. While the letters from Bahia and Rio Grande do Norte revealed the use of lhe with respective frequencies of 51\% and 100\%, in Pernambuco, the $o / a$ clitic was the most frequently used, at 59\%. Finally, the letters from São Paulo had the lowest number of occurrences (only three), which does not provide robust results. In this location, there was only a single occurrence of $t e$, você and $o / a$.

The coexistence of the tu and você subsystems of address led to the development of a paradigm towards Brazilian voceamento: você began to be used in subject role, but the clitic te was kept as an accusative complement, most frequently used in the most populous region of Brazil (Southeast), as set out in Map 4.

12 We have not mentioned the results from São Paulo on the map due to the low number of occurrences (three occurrences of accusative forms in letters with você). 
The regional differences in Brazil evidence the speed with which this change took place in the second person pronominal system at a time in which we can identify distinct systems in the Brazilian geographical space. Regarding the accusative, we observed a faster implementation of forms from the você paradigm in the Northeast than in the Southeast, which most frequently used the original clitic te.

\subsection{The variants of second person dative complements in Brazilian letters from the 19th and 20th centuries}

We analyzed as datives the internal arguments of transitive and ditransitive verbs that receive the thematic role of target or source of an action. Datives, differently from accusatives, prototypically represent entities with the [+animate] feature. In representing the second person singular in Brazilian Portuguese, we can find datives in the form of clitics, prepositional phrases (in most cases, with the prepositions $a$ or para $^{13}$ ) and also with no phonetic realization (null dative).

Originally, the second person dative in Portuguese was represented by forms from the $t u$ paradigm: the clitic te (example (18)) and the prepositional phrase a/para ti (example (19)). With the emergence of the new você pronoun, however, new forms became licensed for the dative, like the clitic lhe (example (20)) and the prepositional phrase a/para você (examples (21) and (22)). In the following examples, we illustrate the variants of the dative with data taken from the corpus under analysis, to which we add the possibility of a null dative (example (22)).

(18) O Tito vai bem, hoje vai te escrever, elle gostou muito do Rio. [1st half of the 20th century, RJ]

The Tito goes well, today go you to-write, he liked much of Rio

'Tito is doing well, today he will write to you, he liked Rio very much'

13 There are few cases in which the dative can be introduced by a different preposition. For example, when this argument receives the thematic role of source from the verb, it is more natural (if not the only possibility) for it to be introduced by the preposition de, especially in BP: $O$ João tomou a carta de você ('John took the letter from you') - O João lhe tomou a carta ('John you took the letter'); A Maria roubou de ti um beijo ('Maria stole from you a kiss') > A Maria te roubou um beijo ('Maria you stole a kiss'). 
(19) se não fosse isso seria capaz de ficar a noite toda escrevendo para ti. [1st half of the 20th century, RJ]

if not were this would-be capable of to-stay the night all writing to you

'if it weren’t for this, I could stay up all night writing to you'

(20) Hontem telegraphei a \# Velloso para lhe dar mais dinheiro. [1st half of the 20th century, PE]

Yesterday [I]telegraphed to \# Velloso to you to-give more money

'Yesterday I telegraphed Velloso to give you more money'

(21) Muito agradeço $a$ você, mamãe. [1st half of the 20th century, MG]

Much [I]thank to you, mom

'Thank you very much, mom'

(22) Lucinha, mandei uma foto prá você. [2nd half of the 20th century, RN]

Lucinha, [I]sent a photo to you

'Lucinha, I sent a photo to you'

(23) Fora o que já ø contei, não tenho feito nada de extraordinariamente interessante. [2nd half of the 20th century, RJ]

Out of what already $\varnothing[\mathrm{I}]$ told, not [I]have done nothing of extraordinarily interesting

'Except for what I'vealready told you, Ihaven’t done anything extraordinarily interesting'

As we have already discussed in relation to the accusative, the main objective of this investigation is to determine to what extent the forms related to the você paradigm accompanied the new subject pronoun. Moreover, we pose another question: does the implementation of the innovative forms take place in a generalized way in Brazilian Portuguese or is it possible to find dialectical differences? In Table 8, we present the distribution of the variant forms of the dative identified in the corpus of personal letters.

Overall, we can see that the dative clitics te (from the tu paradigm) and lhe (from the voce paradigm) were the most frequent variants in the entire sample: together, these forms correspond to more than $70 \%$ of the occurrences observed. The third most 


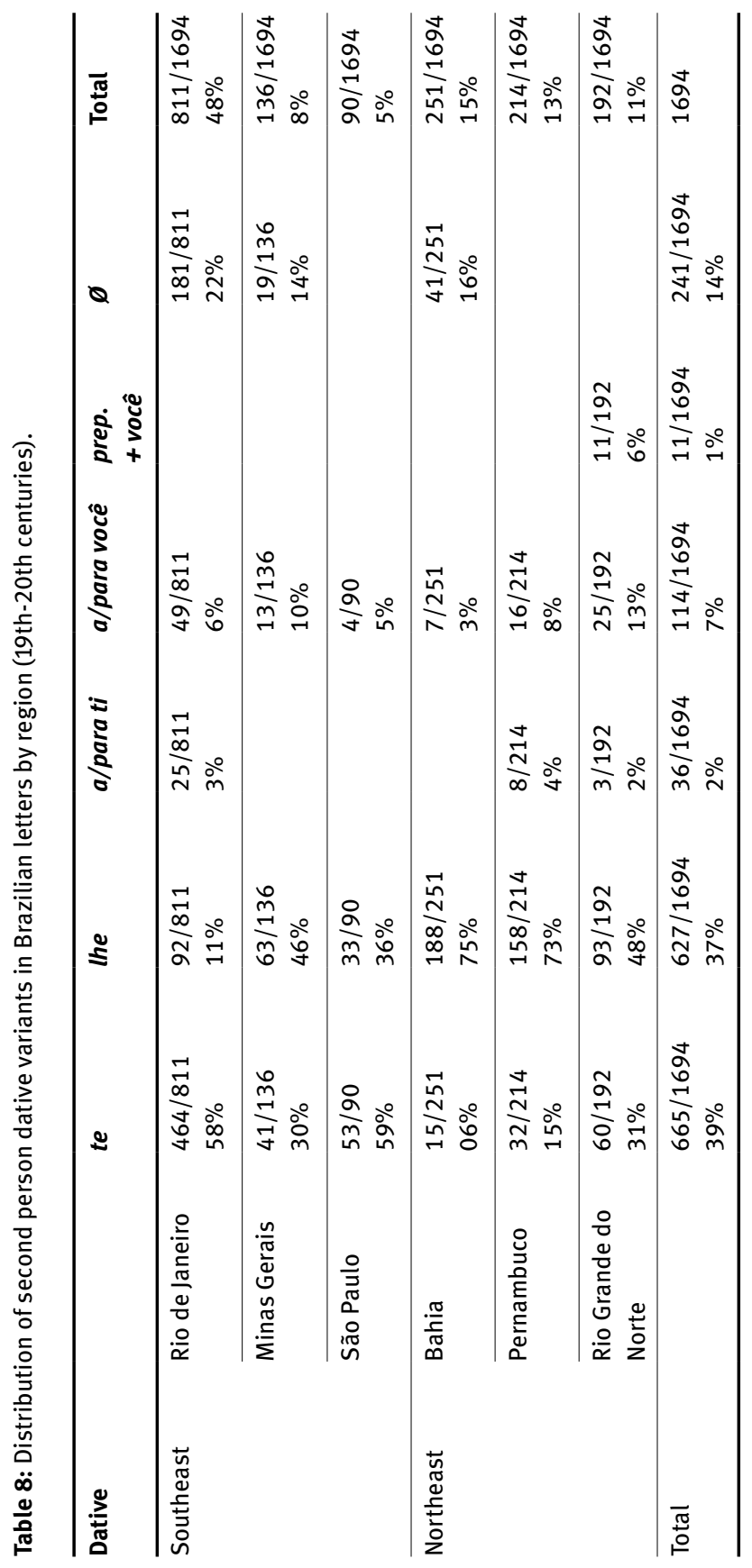


frequent variant was the null dative (14\%), which did not occur in all of the letters in the sample. In relation to prepositional phrases, we observe that the prepositional phrase a/para você was the most frequent (7\% - 114/1694) in the two regions, in comparison to a/para ti $(2 \%-36 / 1694)$, which was very sporadic in the letters analyzed.

We see a clear difference between the two regions regarding the most frequent dative strategies. This enables us to outline an isogloss to determine the forms in competition, with areas of transition. On the one hand, in the Northeastern region, the clitic lhe was predominant in the three states analyzed. On the other, in the Southeastern region, the clitic te predominated in most of them (Rio de Janeiro and São Paulo), with the exception of Minas Gerais, in which lhe overlaps with the clitic dative te. It is worth noting that the state of Minas Gerais shares a geographical border with each region.

Adopting the same perspective used for the analysis of the accusative, we now examine the consequences for the second person dative in a more voceante paradigm. Therefore, in Table 9, we chose only those occurrences of the second person dative in the letters in which the author exclusively used the você pronoun in subject position.

Table 9: Distribution of the second person dative variants in letters with the você subject, by Brazilian region (19th-20th centuries).

\begin{tabular}{|c|c|c|c|c|c|c|c|}
\hline \multirow[t]{2}{*}{ Dative } & & \multicolumn{6}{|c|}{ 2P Dative forms and the use of the você subject } \\
\hline & & te & Ihe & $a / p a r a t i$ & $\begin{array}{l}\text { a/para } \\
\text { você }\end{array}$ & $\begin{array}{l}\text { prep. } \\
+ \text { você }\end{array}$ & $\varnothing$ \\
\hline \multirow[t]{6}{*}{ Southeast } & Rio de Janeiro & $85 / 275$ & $75 / 275$ & $1 / 275$ & $34 / 275$ & & $80 / 275$ \\
\hline & & $31 \%$ & $27 \%$ & $1 \%$ & $12 \%$ & & $29 \%$ \\
\hline & Minas Gerais & $19 / 107$ & $62 / 107$ & & $11 / 107$ & & $15 / 107$ \\
\hline & & $18 \%$ & $58 \%$ & & $10 \%$ & & $14 \%$ \\
\hline & São Paulo & $7 / 16$ & $07 / 16$ & & $2 / 16$ & & \\
\hline & & $44 \%$ & $44 \%$ & & $12 \%$ & & \\
\hline \multirow[t]{6}{*}{ Northeast } & Bahia & $4 / 206$ & $164 / 206$ & & $7 / 206$ & & $31 / 206$ \\
\hline & & $2 \%$ & $80 \%$ & & $3 \%$ & & $15 \%$ \\
\hline & Pernambuco & & $134 / 149$ & & $13 / 149$ & & \\
\hline & & & $90 \%$ & & $10 \%$ & & \\
\hline & Rio Grande do & & $42 / 49$ & & $7 / 49$ & & \\
\hline & Norte & & $86 \%$ & & $14 \%$ & & \\
\hline
\end{tabular}

The results seen here are not so different from those in Table 8 with all of the data. In the data taken from the samples from the Southeastern region, we observe that even in the letters in which the sender uses only você in subject position, we find 
fairly high rates of the te clitic: $44 \%$ in the SP sample, $31 \%$ in the RJ sample and $18 \%$ in the MG sample. By contrast, the data collected in the samples from the Northeastern region suggest a more significative implementation of the lhe clitic, associated with the use of the você subject: $80 \%$ in the BA sample, $90 \%$ in the PE sample and $86 \%$ in the RN sample.

In conclusion, we can say that there is variation in the use of second person dative clitics that is directly correlated with the geographical variable: lhe in the Northeastern region and te in the Southeastern region, with the state of Minas Gerais marking an area of transition, at least, in the letters analyzed (Map 5).
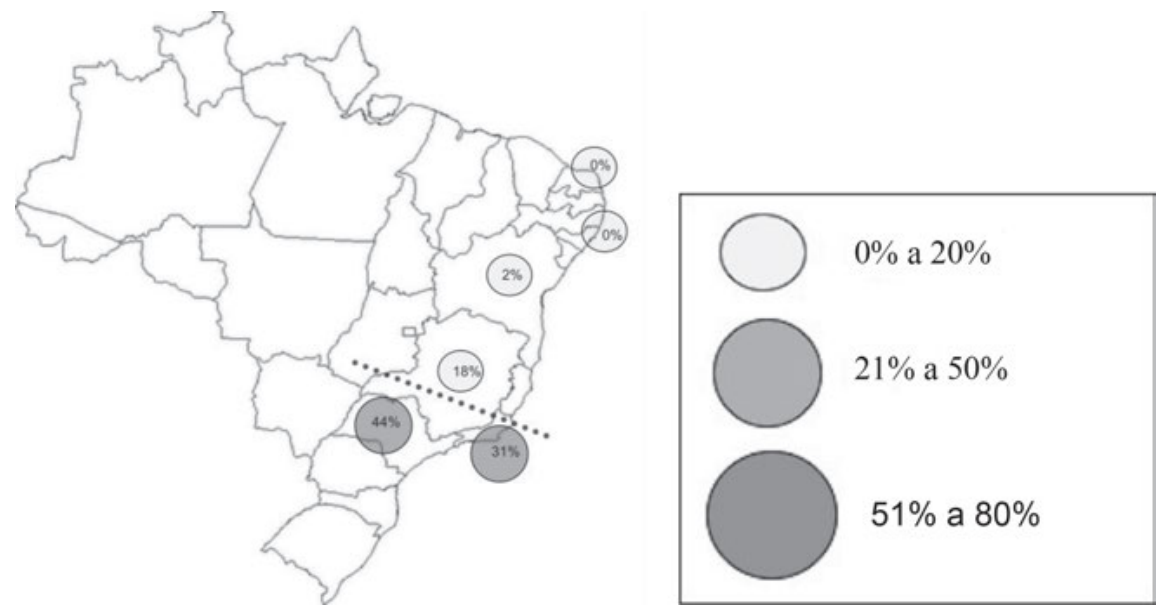

Map 5: The dative clitic te in letters with the você subject (19th-20th centuries).

These regional differences disappear when we focus on the prepositional variants: the variant a para você was the most frequent in the two regions in comparison to the a para ti variant. There was only one occurrence of the latter, in the RJ sample. This result reveals that the a para você variant seems to have followed the implementation of você in subject position more intensely, in detriment to the $a \sim$ para ti variant, which tends to disappear to the extent that the $t u$ pronoun is no longer used in subject position.

Contrasting these results with what is seen in the Spanish voseo system, we have shown that the Southeastern region - this time excluding Minas Gerais reveals behavior that is similar to the voseante regions, since the te clitic was the most frequently used strategy. On the other hand, considering the use of prepositional phrases for expressing the dative, the voseante and voceante systems coincide, in which the innovative variant prep.+ vos/você occupies the position of prepositional complement. 


\subsection{The variants of second person oblique complements in Brazilian letters from the 19th and 20th centuries}

In addition to accusatives and datives, we also consider other constituents that can act as complements for some verbs, namely, obliques. Obliques are characterized by a wide variety of forms and semantic nuances that they can take on; they are always tonic and introduced obligatorily by a preposition ${ }^{14}$ (for example, com, de, em, sem, por 'with, of, in, without, by'). Another characteristic of obliques is the fact that they cannot be substituted by a clitic pronoun (for example: todas as noites, eu sonho com você 'every night I dream with you' > * todas as noites eu lhe sonho “*every night I you dream').

With respect to the second person, there are three variant forms of the oblique in Brazilian Portuguese: "prep. + ti" (examples (24) and (25)), related to the paradigm of the tu pronoun; contigo ( $<$ com + tigo < tecum) (example (26)), related to the $t u$ pronoun; and "prep. + você", related to the paradigm of the você pronoun (examples (27) to (29)).

(24) tu mereces muito mais minha flor, sem ti morrerei. [1st half of the 20th century, RJ]

you deserve much more my flower, without you [I]will-die

'you deserve much more my flower, without you, I will die'

(25) porque em ti reside a creatura que me dá toda a alegria. [1st half of the 20th century, RJ]

because in you resides the creature that me gives all the happiness

'because in you resides the creature that gives me all the happiness'

(26) quero beijar-te loucamente, furiosamente, como quem deseja sorver-te em beijos e em beijos finar-se comtigo. [1st half of the 20th century, PE]

[I]want to-kiss-you crazily, furiously, with who desires devour-you in kisses and in kisses faint with you

'I want to kiss you crazily, furiously, as if I wanted to cover you in kisses and in kisses faint with you'

14 The exception is the form contigo, the result of a specific evolutionary process: Latin te cum > archaic Portuguese tigo > com tigo > modern Portuguese contigo. As we can see, in the archaic phase of Portuguese, this form was also prepositional, before the preposition com became agglutinated to the archaic pronoun tigo. 
(27) eu confio muito em você. [2nd half of the 20th century, RN]

I trust much in you

'I trust you very much'

(28) tendo perguntado por você com muito interesse. [1st half of the 20th century, MG]

having asked for you with much interest

'having asked about you with much interest'

(29) eu sempre simpatizei com você. [1st half of the 20th century, RN]

I always sympathized with you

'I have always liked you'

The previous questions, raised during the presentation of the accusative and dative data, also apply to the oblique: can we say that the oblique forms related to você follow the emergence of this pronoun in subject position? Does the emergence of these forms occur generally in Brazilian Portuguese or variably, according to the dialectical differences already presented? To this end, we will discuss these questions for obliques, based on Table 10, which presents the distribution of the variant oblique forms taken from the corpus of personal letters.

Table 10: Distribution of second person oblique variants in Brazilian letters by region (19th-20th centuries).

\begin{tabular}{llllll}
\hline Oblique & & contigo & prep. + ti & prep. + você & Total \\
\hline Southeast & Rio de Janeiro & $40 / 380$ & $172 / 380$ & $168 / 380$ & $380 / 511$ \\
& & $11 \%$ & $45 \%$ & $44 \%$ & $74 \%$ \\
\cline { 2 - 6 } & Minas Gerais & & $2 / 16$ & $14 / 16$ & $15 / 511$ \\
& & & $12 \%$ & $88 \%$ & $3 \%$ \\
\cline { 2 - 6 } & São Paulo & & $1 / 1$ & $1 / 511$ \\
& & & & $100 \%$ & $<1 \%$ \\
\hline \multirow{2}{*}{ Northeast } & Bahia & & $12 / 32$ & $20 / 32$ & $32 / 511$ \\
& & & $38 \%$ & $62 \%$ & $6 \%$ \\
\cline { 2 - 6 } & Pernambuco & & & $72 / 72$ & $72 / 511$ \\
& & & $100 \%$ & $14 \%$ \\
\cline { 2 - 6 } & Rio Grande do Norte & & $186 / 511$ & $285 / 511$ & 511 \\
\hline Total & & $40 / 511$ & $56 \%$ & $56 \%$ & \\
\hline & & $8 \%$ & $36 \%$ & \\
\hline
\end{tabular}


In general, we can say that the overall results for obliques suggest a usage that is very different for these constituents in comparison to what we observed for accusatives and datives. The oblique forms related to the você paradigm predominated over the forms related to the $t u$ paradigm, independently of the location of the sample analyzed. Altogether, the results showed 56\% prep. + você against $36 \%$ prep. $+t i$. The only exception was the sample from RJ, in which we observed a certain balance between the variants related to você (prep. + você with 44\%) and the variants related to $t u$ (prep. $+t i$ with 45\%). The occurrences of contigo only appeared in the sample from RJ: $8 \%$ of the overall data. The only occurrence in the SP sample was precisely with the preposition followed by você, as seen in example (30).

(30) e que ahi esteve com Você ficando Você de entrar com os restantes 40:300\$000. [1st half of the 20th century, SP]

and that there was with you staying you of to-enter with the remaining 40: $300 \$ 000$

'and there he was with you, and you were to enter with the remaining 40: $300 \$ 000$ '

In Table 11, we present the distribution of obliques in letters with the exclusive use of você in subject position.

Table 11: Distribution of the second person oblique variants in letters with the voce subject, by Brazilian region (19th-20th centuries).

\begin{tabular}{llll}
\hline Oblique & \multicolumn{2}{c}{ 2P Oblique forms and the use of the você subject } \\
\cline { 3 - 4 } & contigo & prep. $+\mathbf{t i}$ & prep. + você \\
\hline Southeast & Rio de Janeiro & $9 / 59$ & $50 / 59$ \\
& & $15 \%$ & $85 \%$ \\
\cline { 2 - 4 } & Minas Gerais & $11 / 11$ \\
& & & $100 \%$ \\
\hline Northeast & Bahia & $9 / 9$ \\
& & & $100 \%$ \\
\cline { 2 - 4 } & Pernambuco & $17 / 17$ \\
& & & $100 \%$ \\
\cline { 2 - 4 } & Rio Grande do Norte & $1 / 1$ \\
& & $100 \%$ \\
\hline
\end{tabular}


This overview based on letters with the exclusive use of você in subject position confirms that, in the oblique role, voceamento spread more extensively in the BP system than in the other functions (accusative and dative). In both regions, with the exception of Rio de Janeiro, which made use of the você-tu subsystem, the use of prepositional phrases with você is practically categorical (100\%). Considering these results, it seems logical to claim that the emergence of the você pronoun in subject position is reflected, to a great extent, in the use of second person obliques: in the six Brazilian locations studied, the oblique forms related to você were predominant. These results constitute a meeting point between Brazilian voceamento and Hispanic voseo, in which we observe the vos form as a prepositional complement, in constituents with the oblique function.

Regarding the oblique forms related to the $t u$ pronoun, the data from the corpus of personal letters allow us to claim that these variants have not been kept in the system given the presence of você in subject position. While, in the overall results, they only occurred in the samples from $\mathrm{RJ}$ and $\mathrm{PE}$, in the results with the exclusive use of the voce-subject, we only find prep. $+t i$ with a percentage of $15 \%$ in the RJ sample.

\subsection{The variants of the second person (genitive) possessive in Brazilian letters from the 19th and 20th centuries}

Finally, we also considered the possessive forms in the second person singular resulting from the original tu (teu/tua/teus/tuas) and você (seu/sua/seus/suas) paradigms. The possessive pronoun, also called the genitive, is traditionally a constituent belonging to the noun phrase, which carries information about person. Moreover, the possessive is a genitive argument of the noun with which it establishes a thematic relation (Castro 2006), which, among others, can be that of possession. We point out that possession is not the only thematic relation fulfilled by the possessive, established between the possessor and the object possessed. This is why we do not define possessives here by a single criterion that privileges exclusively the semantic expression of possession.

Historically, the possessive seu and its variants, in the early stages of Portuguese, only made reference to the new third person (ele/ela) forms coming from the Latin demonstrative ille. With the inclusion of Vossa mercê in the system, around the 15th century, the original third person possessive started to appear in the system of the second person forms of address, due to the remaining properties of class origin in the noun phrase, which is involved in this pronominalization process. Therefore, in the medieval period, seu, related to the nominal forms Vossa mercê, Vossa Senhoria and Vossa Excelência, became a variant of vosso, 
Table 12: Distribution of second person genitive variants in Brazilian letters by region (19th-20th centuries).

\begin{tabular}{lllll}
\hline Genitive & & teu & seu & Total \\
\hline Southeast & Rio de Janeiro & $1002 / 1300$ & $298 / 1300$ & $1300 / 2225$ \\
& & $77 \%$ & $23 \%$ & $58 \%$ \\
\cline { 2 - 5 } & Minas Gerais & $29 / 146$ & $117 / 146$ & $146 / 2225$ \\
& & $20 \%$ & $80 \%$ & $6 \%$ \\
\cline { 2 - 5 } & São Paulo & $46 / 108$ & $62 / 108$ & $108 / 2225$ \\
& & $43 \%$ & $57 \%$ & $5 \%$ \\
\hline Northeast & Bahia & $1 / 105$ & $104 / 105$ & $105 / 2225$ \\
& & $1 \%$ & $99 \%$ & $5 \%$ \\
\cline { 2 - 5 } & Pernambuco & $67 / 249$ & $182 / 249$ & $249 / 2225$ \\
& & $27 \%$ & $73 \%$ & $11 \%$ \\
\cline { 2 - 5 } & Rio Grande do Norte & $119 / 317$ & $198 / 317$ & $317 / 2225$ \\
& & $37 \%$ & $63 \%$ & $14 \%$ \\
\cline { 2 - 5 } & Total & $1264 / 2225$ & $961 / 2225$ & 2225 \\
& & $57 \%$ & $43 \%$ & \\
\hline
\end{tabular}

a genitive corresponding to vós, expressing deference, in the field of linguistic politeness to the interlocutor. With the grammaticalization of Vossa mercê $>$ você, starting from the moment in which você moved into the realm of intimacy, the possessive seu, originally from você, started to coexist with the possessive teu, originally from the intimate pronoun $t u$.

Table 12 shows the overall distribution of teu and seu, according to the analysis of the corpus of personal letters used in this study, considering different Brazilian locations.

Although the possessive from of the tu paradigm (teu) is more frequent than that of você (seu) with $57 \%$ against $43 \%$, basically due to the predominance of the data from the Rio de Janeiro sample, the possessive seu is used more often in five of the six locations from both regions. These results on the possessive in geographic terms are very similar to what we have seen with oblique complements: predominance of the genitive form seu belonging to the você paradigm in the Northeastern and Southeastern regions, with the exception again of Rio de Janeiro in which the teu form from the tu paradigm dominates. Examples (31) to (34) illustrate the range of possessive forms.

(31) Quando será a tua vinda a S. Paulo? [1st half of the 20th century, MG]

When will-be the your arrival to S. Paulo

'When will you arrive in S. Paulo?' 
(32) Já logrei o teu perdão. [1st half of the 20th century, PE]

Already [I]obtained the your pardon

'I have already earned your forgiveness'

(33) Mas vai preparando o seu espírito. [1st half of the 20th century, MG]

But go preparing the your spirit

'But start preparing your spirit'

(34) Recebi duas cartinha suas e respondo-as. [1st half of the 20th century, PE] [I]received two letter yours and [I]respond-them

'I have received two of your letters and I am answering them'

Next, we set out in Table 13 the results regarding the second person possessives in letters with the exclusive use of você in subject position to analyze the voceante paradigm.

Table 13: Distribution of the second person genitive variants in letters with the você subject, by Brazilian region (19th-20th centuries).

\begin{tabular}{|c|c|c|c|}
\hline \multirow[t]{2}{*}{ Genitive } & & \multicolumn{2}{|c|}{ 2P Genitive forms and the use of the você subjec } \\
\hline & & teu & seu \\
\hline \multirow[t]{6}{*}{ Southeast } & Rio de Janeiro & $35 / 269$ & $234 / 269$ \\
\hline & & $21 \%$ & $79 \%$ \\
\hline & Minas Gerais & & $107 / 107$ \\
\hline & & & $100 \%$ \\
\hline & São Paulo & $3 / 25$ & $22 / 25$ \\
\hline & & $12 \%$ & $88 \%$ \\
\hline \multirow[t]{6}{*}{ Northeast } & Bahia & & $37 / 37$ \\
\hline & & & $100 \%$ \\
\hline & Pernambuco & $2 / 157$ & $155 / 157$ \\
\hline & & $1 \%$ & $99 \%$ \\
\hline & Rio de Janeiro & $10 / 78$ & $68 / 78$ \\
\hline & & $13 \%$ & $87 \%$ \\
\hline
\end{tabular}

The results of the second person possessive variants in letters with the você subject show the more frequently used seu in all locations/regions. This predominance does not, however, prove the categorical use of seu, since the variant teu (from 
$t u)$, though less frequent, still occurred in some locations in the two regions: in the Southeast, in letters from Rio de Janeiro (21\%) and São Paulo (12\%); in the Northeast, in letters from Pernambuco (1\%) and Rio Grande do Norte (13\%).

In contrast to the other grammatical relations, there is a point of divergence between Brazilian voceamento and Hispanic American voseo regarding possessives: while in the latter the original possessive tu/tuyo is chosen, in the former, we see the preferred option is the innovative form seu, from the você paradigm.

Comparing the results obtained for the genitive with the results presented in the previous sections for the positions of accusative, dative and oblique, we provide evidence that, regarding the implementation of forms from the você paradigm following the inclusion of this form in subject position, the behavior of the genitive relation seems to be similar to that of the oblique, due to the high frequency of seu and prep. + você, respectively. In the accusative and dative relations, however, the presence of forms from the $t u$ paradigm is shown to be more salient.

\section{Conclusion}

The inclusion of the grammaticalized pronoun você in the realm of intimacy, previously occupied exclusively by the original $t u$ form, triggered a series of reorganizations in the Portuguese pronominal system. Initially in subject position, we observed a coexistence between the $t u$ and você forms. The other grammatical relations were not immune to the spread of você: third person pronominal forms, revealing the nominal origin Vossa mercê, start to become a part of the second person singular system, in the positions of accusative, dative, oblique and genitive, to a greater or lesser degree of inclusion and distribution. As a result, we have a new paradigm in Brazilian Portuguese, set out in Table 14.

Table 14: Development of a new suppletive second person paradigm.

\begin{tabular}{|c|c|c|c|c|c|}
\hline PB & NOM & $A C$ & DAT & OBL & GEN \\
\hline $\begin{array}{l}\text { Paradigm } 1 \\
\text { (original) }\end{array}$ & tu & te & $\begin{array}{l}\text { te } \\
\text { a/parati }\end{array}$ & $\begin{array}{l}\text { contigo } \\
\text { prep. }+t i\end{array}$ & teu \\
\hline $\begin{array}{l}\text { Paradigm } 2 \\
\text { (resulting from v.m. > você) }\end{array}$ & você & $\begin{array}{l}a / o \\
\text { você }\end{array}$ & $\begin{array}{l}\text { lhe } \\
\text { a/para você }\end{array}$ & prep. + você & seu \\
\hline $\begin{array}{l}\text { Paradigm } 3 \\
\text { (new suppletive paradigm) }\end{array}$ & $\begin{array}{l}\text { tu } \\
\text { você }\end{array}$ & $\begin{array}{l}\text { te } \\
\text { lhe } \\
\text { você }\end{array}$ & $\begin{array}{l}\text { te } \\
\text { lhe } \\
\text { a/para você }\end{array}$ & $\begin{array}{l}\text { contigo } \\
\text { prep. + ti } \\
\text { prep. + você }\end{array}$ & $\begin{array}{l}\text { teu } \\
\text { seu }\end{array}$ \\
\hline
\end{tabular}




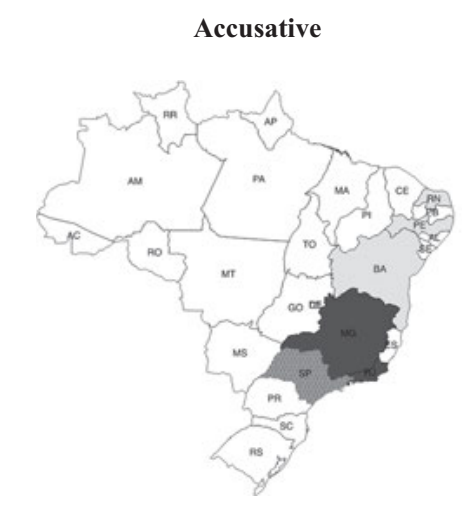

Oblique

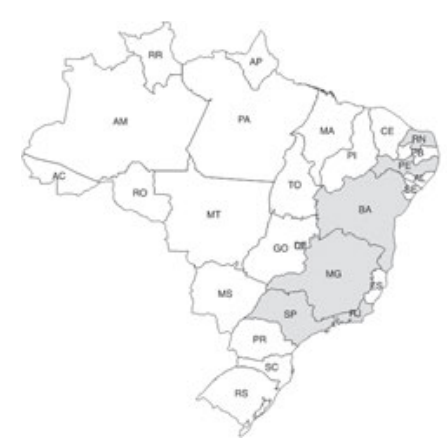

Dative

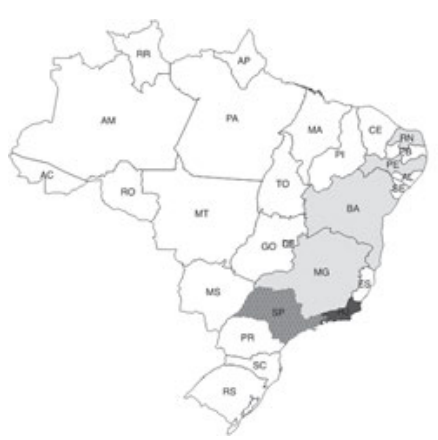

Genitive

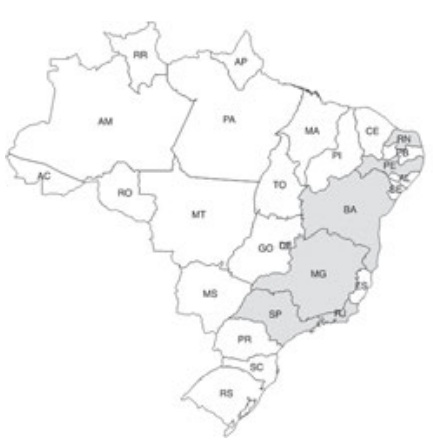

Key:

tu forms

você forms

Map 6: Development of Brazilian voceamento (19th-20th centuries): original vs. innovative forms.

These changes of keeping original forms and implementing new forms can be better visualized in Map 6, in which the lighter shade refers to the innovative forms of the voceante system (você paradigm) and the darker shade refers to the original forms specific to the $t u$ paradigm. Regarding the accusative relation, we observed a faster implementation of forms from the voce paradigm in the Northeast than in the Southeast, where the original clitic te is most frequently used. The linguistic frontier is somewhat different for the dative variants. Minas Gerais, which lies in the Southeast of Brazil, behaves similarly to the Northeast region with greater use of the você forms. The regional differences disappear when we focus on the prepositional variants and genitive. In these grammatical relations, it is possible to observe the implementation of forms from the você paradigm. 
As can be seen, after the inclusion of você in subject position, the implementation of forms from its paradigm in other syntactic contexts did not occur in the same way, or at the same rate, in all regions of Brazil. Consequently, our results confirm the following observation by Conde Silvestre (2007: 143):

\footnotetext{
Changes do not usually affect all speakers of a language evenly, but they are the result of processes of generalization over prolonged periods of time, during which their spread through the system and community progresses at a different rate according to the stage in which the affected variable is found.
}

The sociopragmatic values and the structural contexts of the variant forms need to be more thoroughly analyzed in future studies. In this chapter, we have presented a starting point of a descriptive nature that should and must be reviewed with new data samples and with theoretical-explanatory proposals that shed more light on the issue. The correlation with Hispanic American voseo also requires further development, but we have, for now, a starting point for the discussion of common Ibero-American changes in terms of the second person address systems.

\section{References}

Almeida, Norma Lucia F. de. 2012. Urbanização, escolarização e variação linguística em Feira de Santana-Bahia (século XX). Tabuleiro de Letras 4. 71-85.

Amor Divino, Ludinalva Santos do. 2008. Como trato meu receptor? A propósito do uso de $t u /$ você em Santo Antônio de Jesus-BA. M.A. thesis. Federal University of Bahia.

Andrade, Aroldo Leal de, Mariana Fagundes de Oliveira \& Zenaide de Oliveira Novais Carneiro. 2018. Formas de tratamento em cartas da Bahia. In Lopes (ed.), 107-117.

Balsalobre, Sabrina Rodrigues Garcia \& Vanessa Martins do Monte. 2018. Formas de tratamento em cartas de São Paulo. In Lopes (ed.), 78-90.

Bertolotti, Virginia. 2015. A mí de vos no me trata ni usted ni nadie. Sistemas e historia de las formas de tratamiento en la lengua española en América. Mexico City: UNAM/Universidad de la República de Uruguay.

Brown, Roger \& Albert Gilman. 1960. The pronouns of power and solidarity. In T.A. Sebeok (ed.), Style in language, 253-276. Cambridge-Mass: MIT Press.

Carricaburo, Norma. 1997. El voseo en la literatura argentina. Madrid: Arco/Libros.

Castro, Ana. 2006. On possessives in Portuguese. PhD dissertation: Universidade Nova de Lisboa.

Censo demográfico do Brasil de 1872. Wikipédia, a enciclopédia livre. https://pt.wikipedia. org/w/index.php?title=Censo_demogr\%C3\%A1fico_do_Brasil_de_1872\&oldid=52729284 (23 July, 2018).

Cintra, Luís F. Lindley. 1972. Sobre "formas de tratamento" na língua portuguesa. Lisbon: Livros Horizonte. 
Coelho da Silva, Francielly. 2015. Variação entre os pronomes tu e você na função de sujeito na fala de Natal (RN): uma abordagem sociofuncionalista. M.A. thesis. Federal University of Rio Grande do Norte.

Conde Silvestre, Juán Camilo. 2007. Sociolingüística histórica. Madrid: Gredos.

Demografia do Brasil. Wikipédia, a enciclopédia livre. https://pt.wikipedia.org/w/index. php?title=Demografia_do_Brasil\&oldid=53116893 (12 September, 2018).

Domingos, Tânia Regina Eduardo. 2001. Pronomes de tratamento do português do século XVI: uma gramática de uso. São Paulo: Annablume.

ESTIMATIVAS da população residente no Brasil e unidades da Federação com data de referência em $1^{0}$ de julho de 2015. Rio de Janeiro: IBGE. ftp://ftp.ibge.gov.br/Estimativas_de_ Populacao/Estimativas_2015/estimativa_dou_2015_20150915.pdf (12 September, 2017).

Faraco, Carlos Alberto. 1996. 0 tratamento você em português: uma bordagem histórica. Fragmenta 13. 51-82.

Fontanella de Weinberg, María Beatriz. 1992. La evolución de los usos americanos de segunda persona singular. Lingüística 4. 7-25.

Fontanella de Weinberg, María Beatriz. 1977. La constitución del paradigma pronominal del voseo. Thesaurus 32,2. 227-241.

Gomes, Valéria Severina. 2018. Formas de tratamento em cartas de Pernambuco. In Lopes (ed.), 118-128.

Hummel, Martin, Bettina Kluge \& María Eugenia Vázquez Laslop (eds.). 2010. Formas y fórmulas de tratamiento en el mundo hispánico. México DF/Graz: El Colegio de México/ Karl-Franzens-Universität Graz.

Lapesa, Rafael. 2000. Estudios de morfosintaxis histórica del español. Madrid: Gredos.

Lopes, Célia Regina dos Santos (ed.). 2018. Mudança sintática das classes de palavra: perspectiva funcionalista - História do Português Brasileiro, vol. 4. São Paulo: Editora Contexto.

Lopes, Célia Regina dos Santos \& Janaina Pedreira Fernandes Souza. 2018. Formas de tratamento em cartas do Rio de Janeiro. In Lopes (ed.), 46-66.

Lopes, Célia Regina dos Santos \& Silvia R. Cavalcante. 2011. A cronologia do voceamento no português brasileiro: expansão de você-sujeito e retenção do clítico -te. Lingüística 25. 30-65.

Lucchesi, Dante, Alan Baxter \& Ilza Ribeiro (eds.). 2009. O português afro-brasileiro. Salvador: Editora da Universidade Federal da Bahia.

Luz, Marilina dos Santos. 1958. Fórmulas de tratamento no português arcaico - subsídios para o seu estudo. Revista Portuguesa de Filologia 9. 55-144.

Marcotulio, Leonardo Lennertz. 2015. Sobre la génesis de "Vossa Mercê" en el portugués medieval. Lingüística 31,1. 61-79.

Marcotulio, Leonardo Lennertz. 2014. Formas de tratamento no português arcaico: contribuições do teatro português quinhentista. Confluência 46. 157-200.

Marcotulio, Leonardo Lennertz. 2010. Língua e História: o $2^{\circ}$ marquês do Lavradio e as estratégias linguísticas da escrita no Brasil Colonial. Rio de Janeiro: Ítaca Comunicações.

Moser, Karolin. 2010. San José (Costa Rica): desde los significados pragmáticos del ustedeo en el registro coloquial actual hacia sus primeras manifestaciones en el Valle Central (siglo XVIII). In Hummel et al. (eds.), 671-713.

Mota, Maria Alice. 2008. A variação dos pronomes tu e você no português oral de São João da Ponte (MG). M.A. thesis. Federal University of Minas Gerais. 
Oliveira, Thiago. 2014. Entre o linguístico e o social: complementos dativos de 2a pessoa em cartas cariocas (1880-1980). Master's thesis. Federal University of Rio de Janeiro.

Paredes Silva, Vera Lúcia Pereira. 1996. A variação você/tu na fala carioca. Paper presented in $1^{\circ}$ Encontro de Variação Linguística do Cone Sul. Federal University of Rio Grande do Sul.

Peres, Edenize Ponzo. 2006. 0 uso do você, ocê, cê em Belo Horizonte - um estudo em tempo aparente e em tempo real. Ph.D. Dissertation: Federal University of Minas Gerais.

Placencia, María Elena. 2010. El estudio de formas de tratamiento en Colombia y Ecuador. In Hummel et al. (eds.), 341-373.

Rona, José Pedro. 1967. Geografía y morfología del voseo. Pôrto Alegre: Pontifícia Universidade Católica do Rio Grande do Sul.

Rumeu, Márcia Cristina de Brito, Iracema Aguiar da Cruz \& Nayara Domingues Cardoso. 2018. Formas de tratamento em cartas de Minas Gerais. In Lopes (ed.), 67-77.

Rumeu, Márcia Cristina de Brito. 2004. Para uma história do português no Brasil: formas pronominais e nominais de tratamento em cartas setecentistas e oitocentistas. M.A. thesis. Federal University of Rio de Janeiro.

Rumeu, Márcia Cristina de Brito. 2013. Língua e sociedade: a história do pronome 'você' no português brasileiro. Rio de Janeiro: Ítaca.

Santos, Viviane Maia dos. 2012. "Tu vai para onde?... Você vai para onde": manifestações da segunda pessoa na fala carioca. M.A. thesis. Federal University of Rio de Janeiro.

Scherre, Maria Marta Pereira et al. 2009. Usos dos pronomes você e tu no português brasileiro. Comunicação apresentada no // SIMELP - I/ Simpósio Mundial de Estudos de Língua Portuguesa: Universidade de Évora.

Scherre, Maria Marta Pereira, Edilene Patrícia Andrade Dias, Carolina Andrade \& Germano Ferreira Martins. 2015. Usos dos pronomes você e tu. In Marco Antônio Martins \& Jussara Abraçado. Mapeamento sociolinguístico do português brasileiro, 133-172. São Paulo: Editora Contexto.

Sette, Neide Durães. 1980. Formas de tratamento no português coloquial. M.A. thesis. Federal University of Pernambuco.

Souza, Camila. 2014. Eu te amo, eu lhe adoro, eu quero você: a variação das formas de acusativo de 2 a pessoa em cartas pessoais (1880-1980). Master's thesis. Federal University of Rio de Janeiro.

Souza, Janaína. 2012. Mapeando a entrada do você no quadro pronominal: análise de cartas familiares dos séculos XIX-XX. Master's thesis. Federal University of Rio de Janeiro. 
